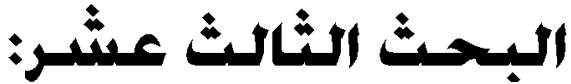

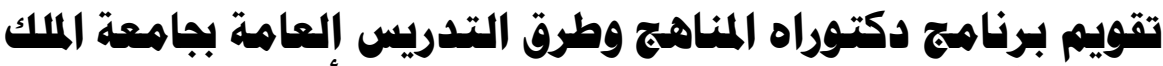 خالد في ضوي همايير هيئة البراهج وهئ التربوية الأهريكية (الكيب)}

\section{: إلحاكإ}

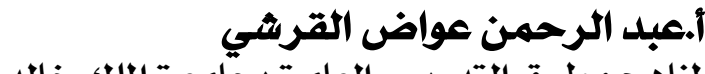

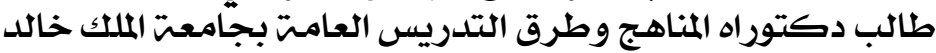

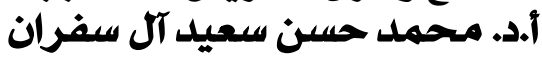

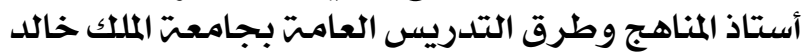

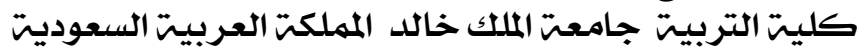





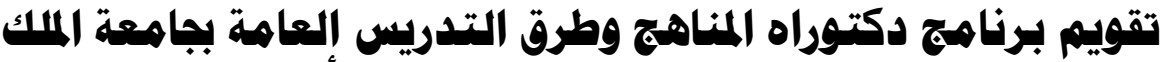

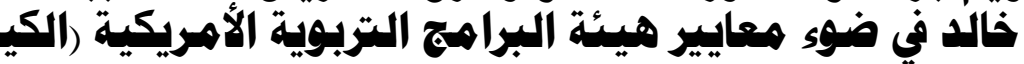

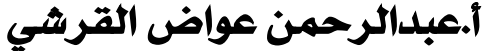

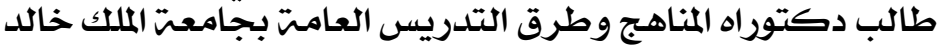

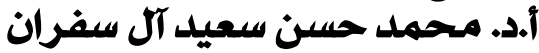

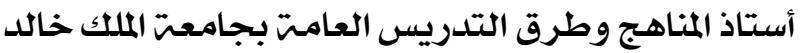

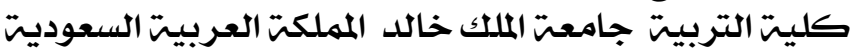

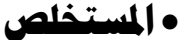

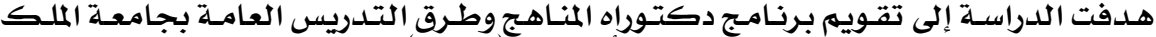

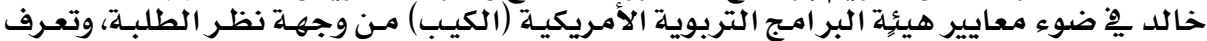

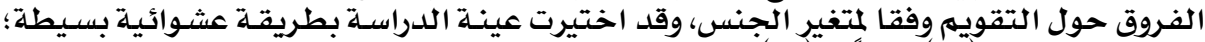

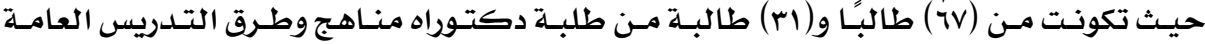

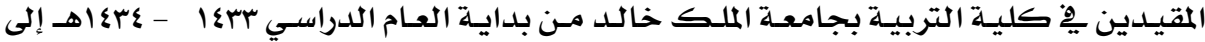

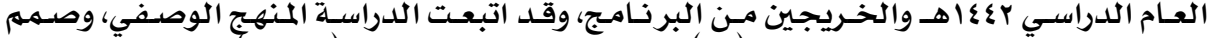

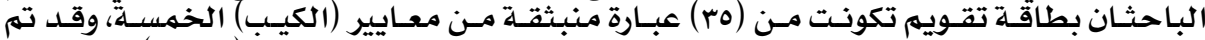

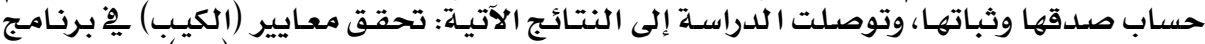

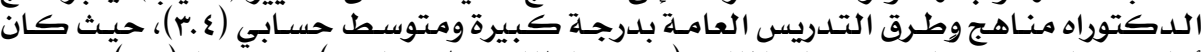

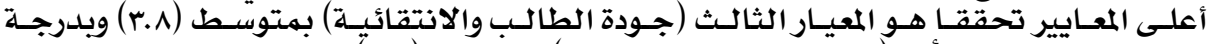

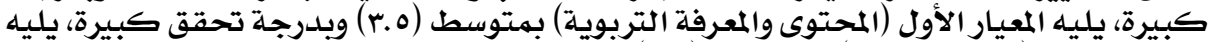

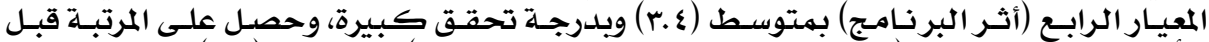

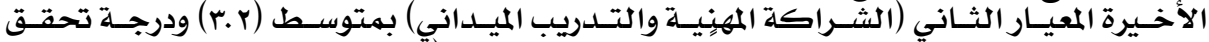

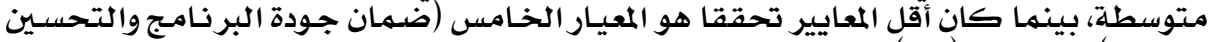

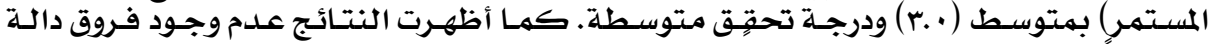

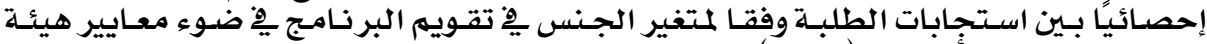

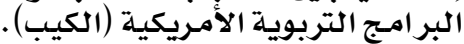

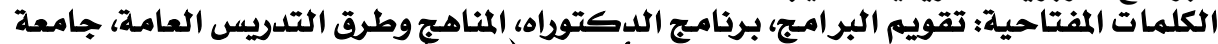

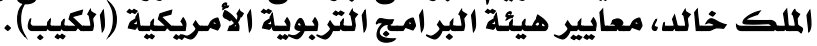

Evaluation of the PHD Program, General Curricula and Teaching Means at King Khalid University in Light of the Standards of the American Educational Programs Authority (CAEP)

Abdulrahman Awwad Alqurashi \& Prof. Mohammed Hasan Saeed Al-Safran $\underline{\text { Abstract }}$

The study aimed to evaluate the PhD program, curricula, and general teaching methods at King Khalid University in light of American Educational Programs Authority (CAEP) standards from students' perspectives, and to identify differences concerning the evaluation according to the gender variable. The study sample was selected in a simple random way, as It consisted of (67) male and (31) female doctoral students, curricula and general teaching methods enrolled in King Khalid University' College of Education from the beginning of the academic year 1433-1434 AH to the academic year $1442 \mathrm{AH}$ and those graduated from the program. The study followed the descriptive approach, and the researchers designed an evaluation card consisting of (35) statements emanating from the five (CAEP) criteria, their validity and stability were calculated, and the study concluded

\section{r^q}




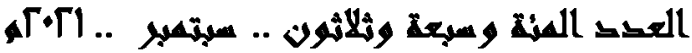

the following outcomes:The criteria for (CAEP) in the doctoral program achieve general curricula and teaching methods to a large degree and an arithmetic mean at (3.4), where the highest standards achieved was the third criterion (Student Quality and Selectivity) with mean of (3.8) and at large degree, followed by the first criterion (Educational Content and Knowledge) with a mean of (3.5) and with a large degree of verification, followed by the fourth criterion (Program Effect) with a mean at (3.4) which came at large degree of verification, then the second criterion (Professional Partnership and Field training) was ranked with an average of (3.2) at moderate degree of verification, while the least met criteria was the fifth criterion (Program Quality Assurance and Continuous Improvement) with an average of (3.0) and at moderate degree of achievement. The outcomes also showed that there was no statistically significant variation between students 'responses according to the gender variable in the program's evaluation in light of the standards of the American Educational Programs Authority (CAEP).

Key words: Program Evaluation, Doctoral program, General Curricula and teaching methods, King Khalid University, American Educational Programs Authority Standards (CAEP).

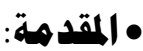

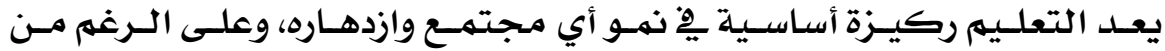

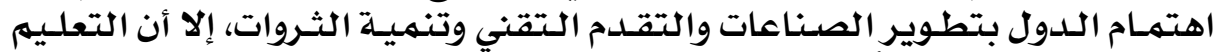

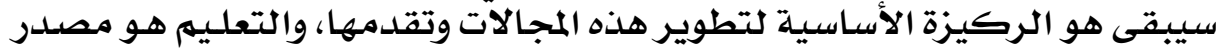

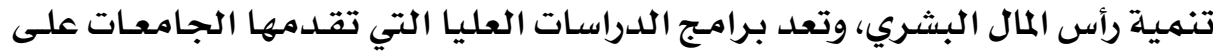

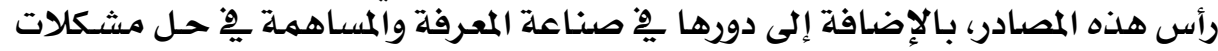

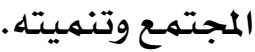

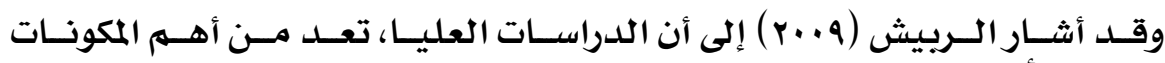

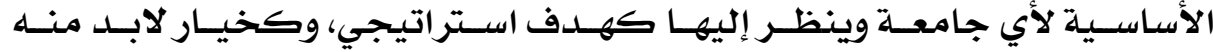

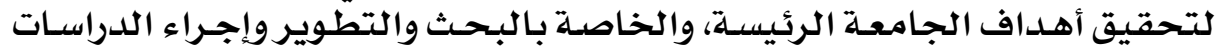

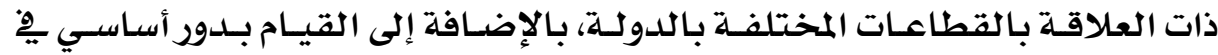

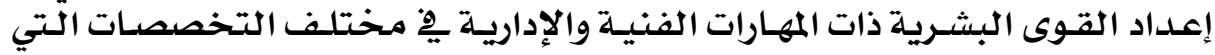

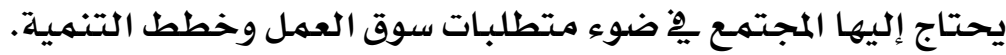

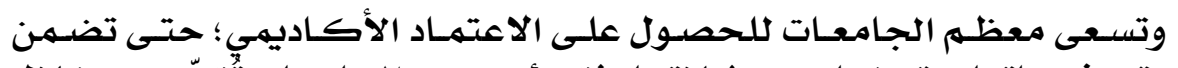

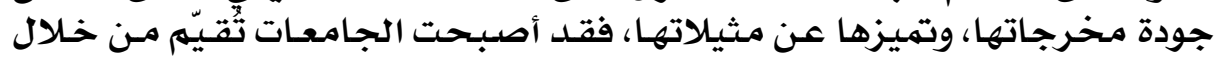

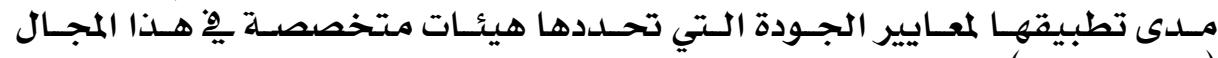

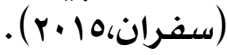

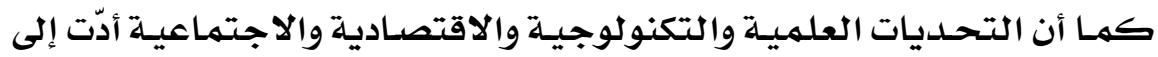

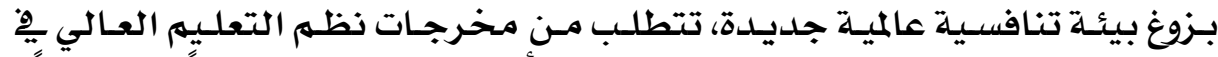

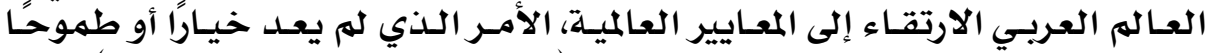

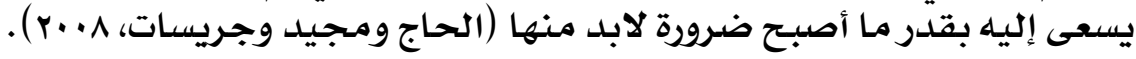




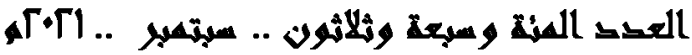

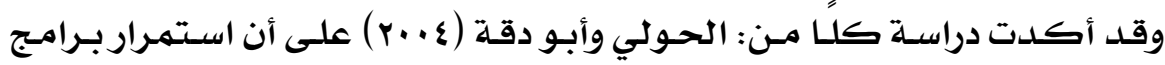

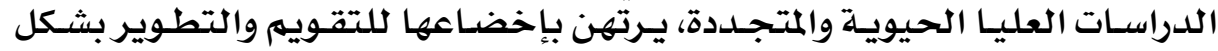

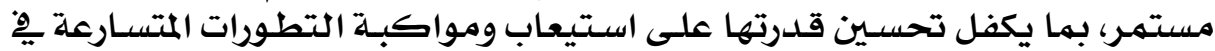

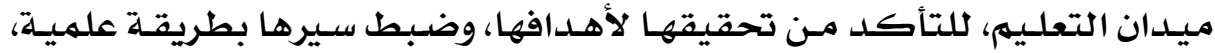
ومعرفة نقاط الضعف، ومحاولة تلافيها ونقاط القوة والعمل على على تعزيزها.

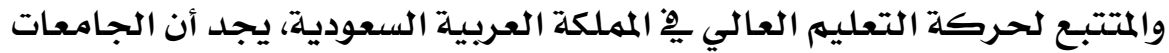

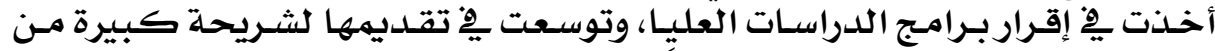

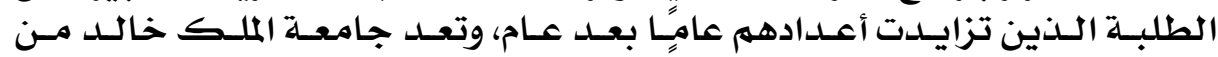

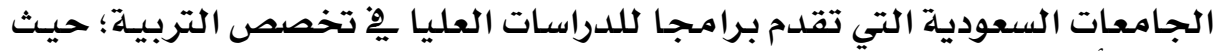

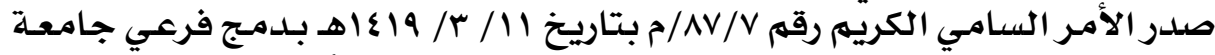

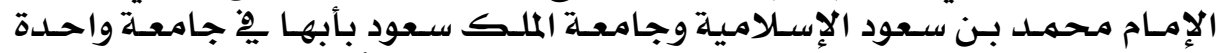

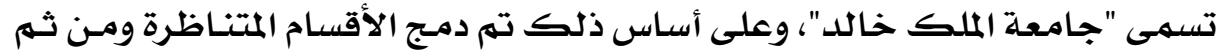

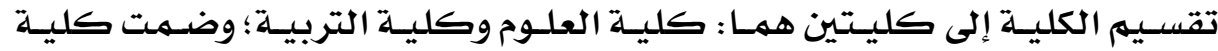

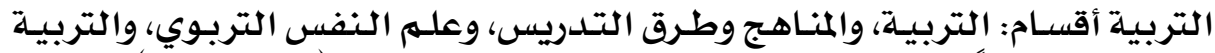

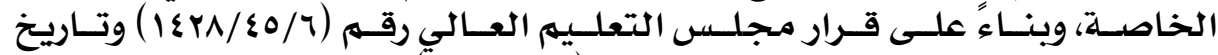

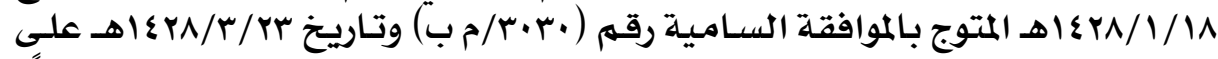

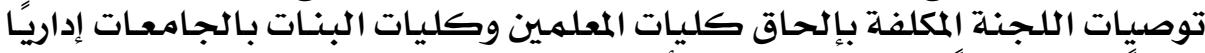

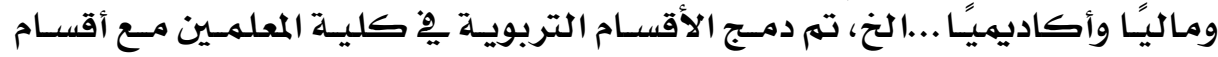

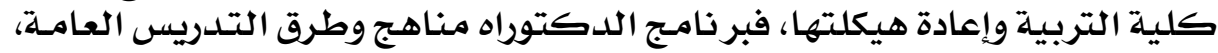

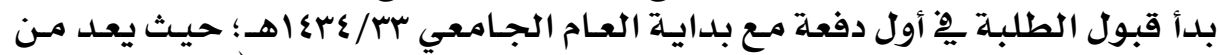

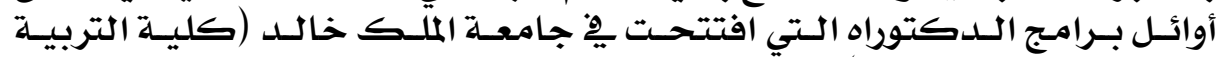

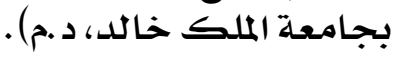

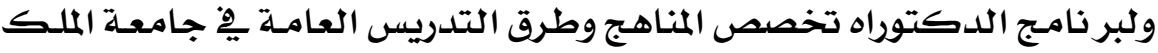

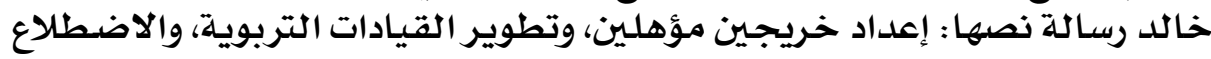

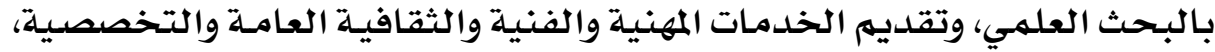

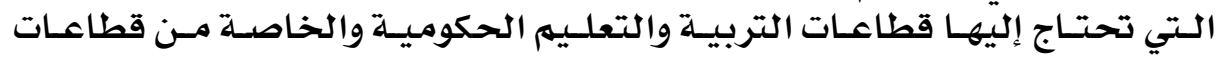

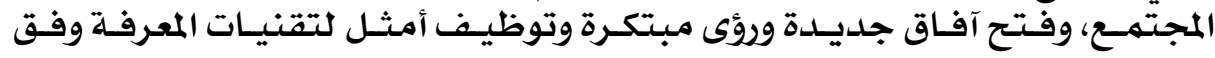

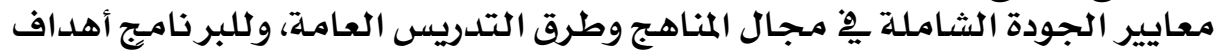

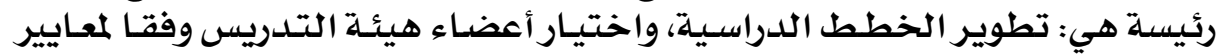

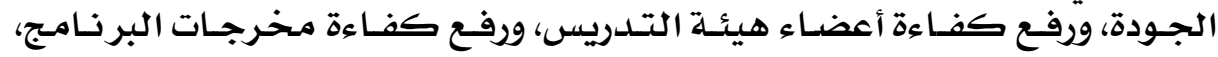

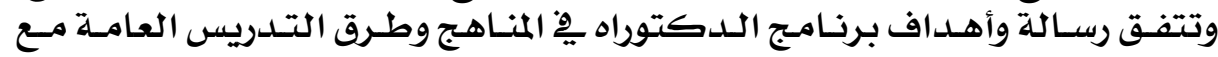

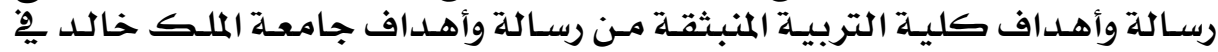

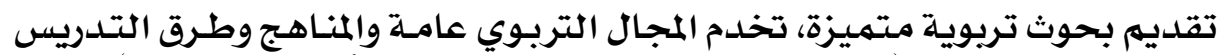

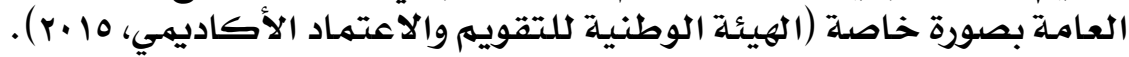

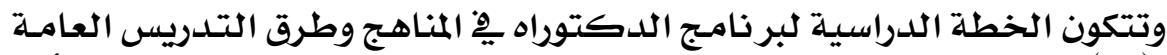

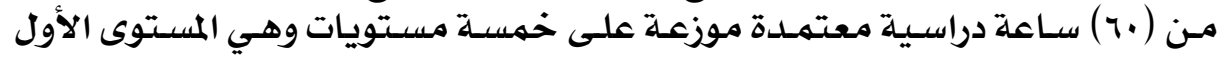

\section{rq}




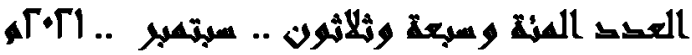

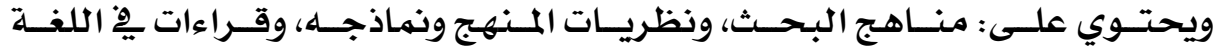

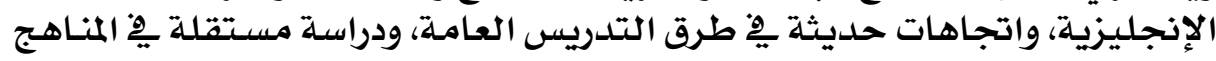

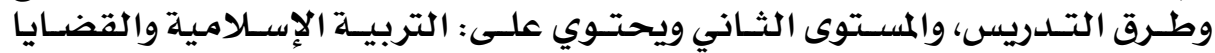

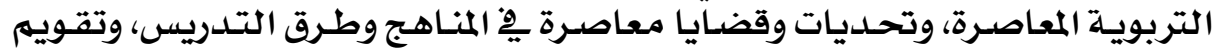

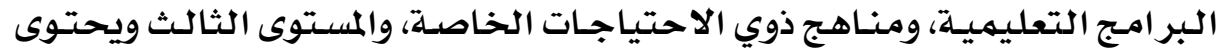

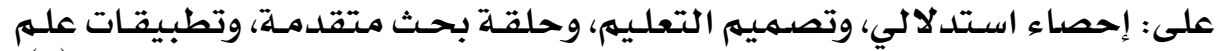

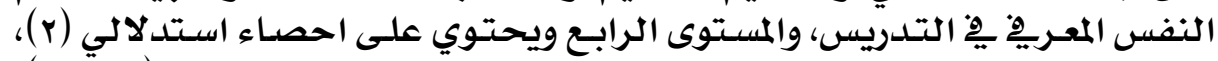

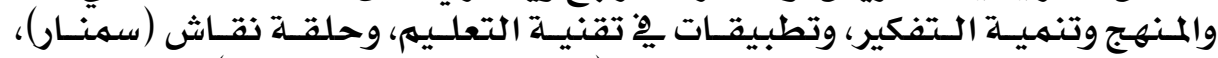

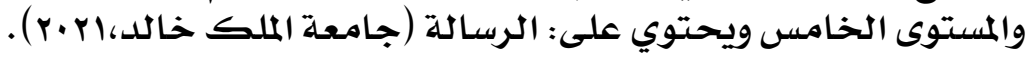

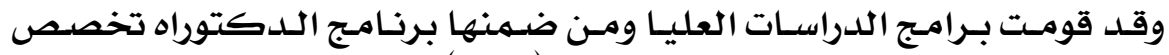

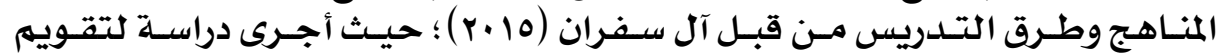

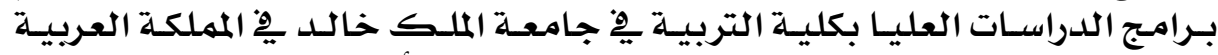

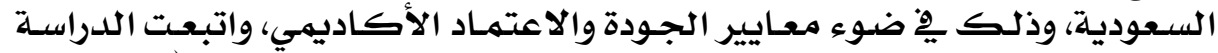

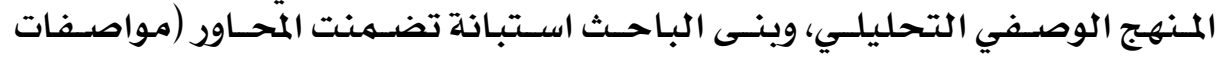

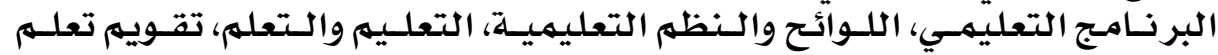

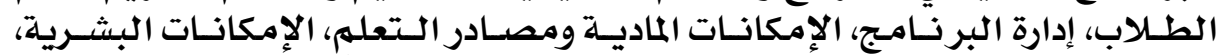

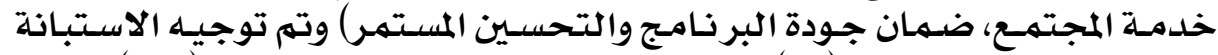

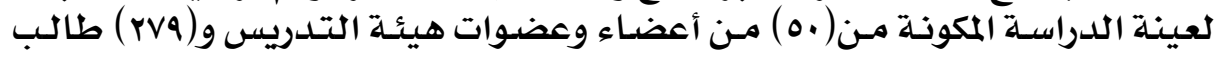

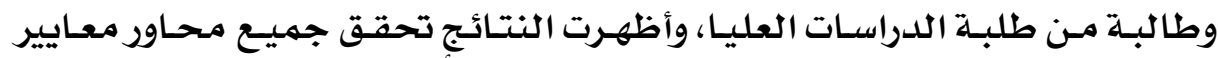

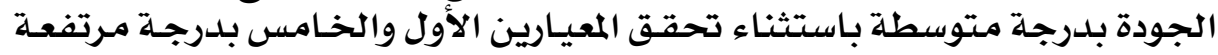

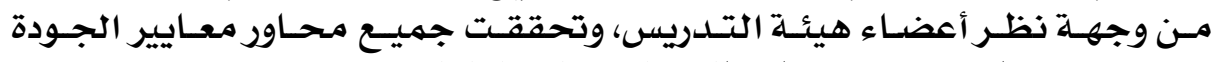
بلدرجة متوسطة مـن وجهة نظر طلبـة الدراسـات العليا.

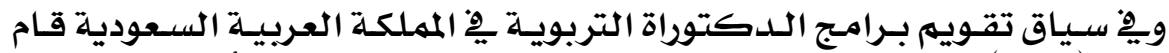

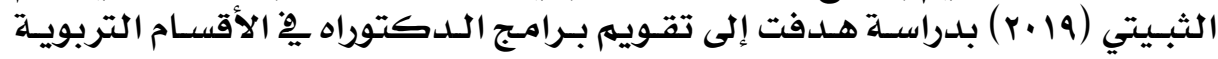

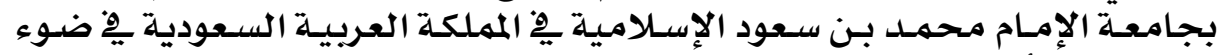

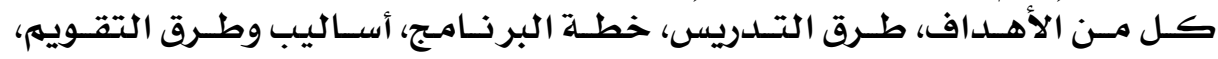

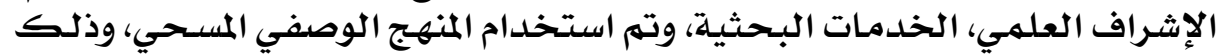

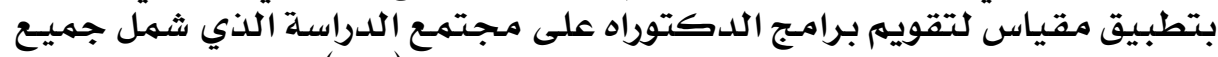

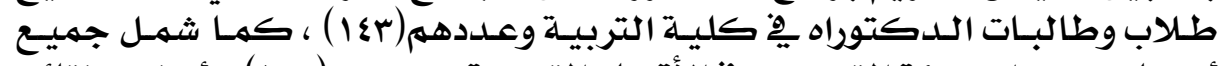

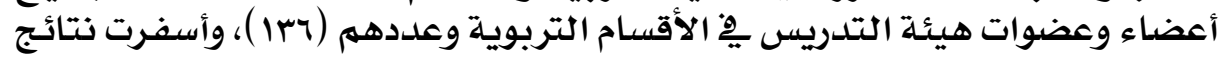

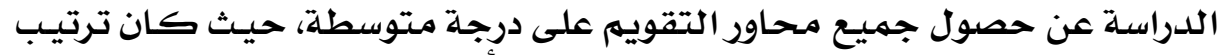

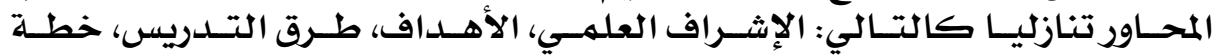

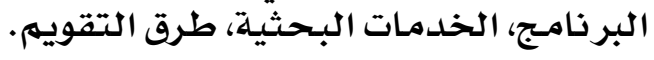

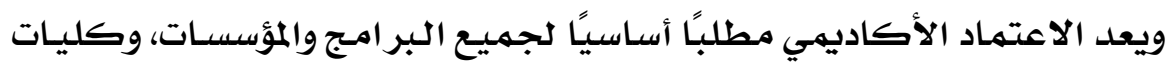

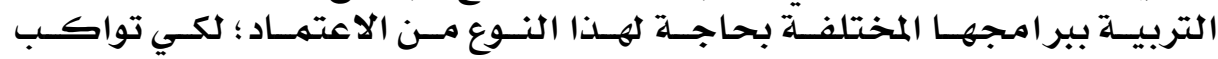

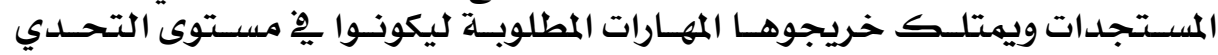

\section{rqY}




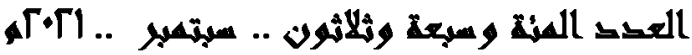

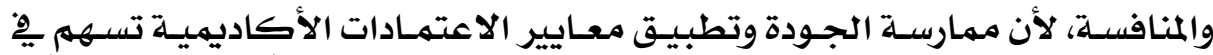

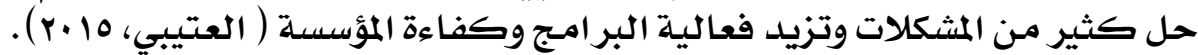

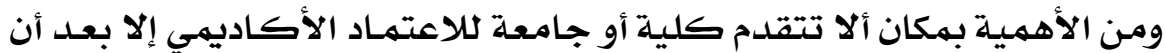

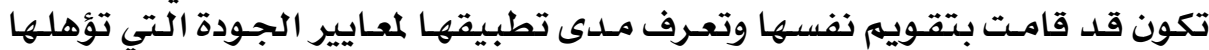

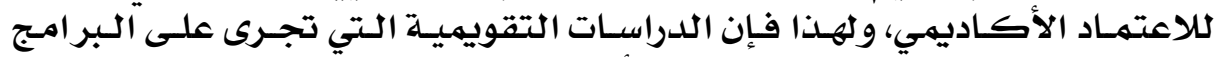

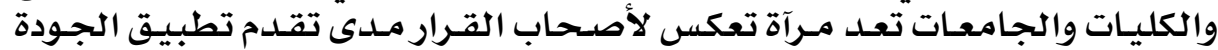

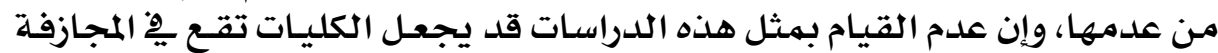

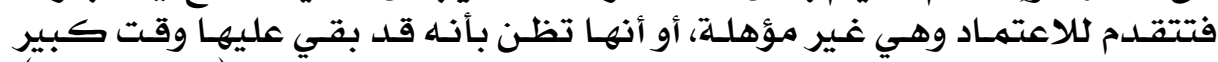

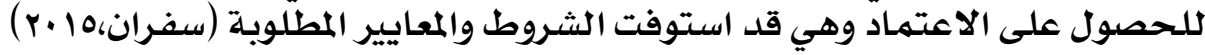

و(الكيـب) (CAEP) هي هيئسة أمريكيـة تعنى بـاعتهـاد البر امـج التربويـة وفقًا

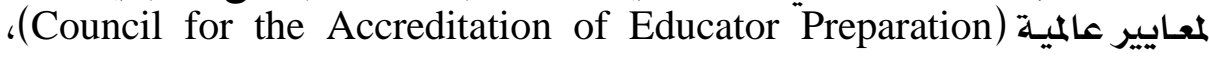

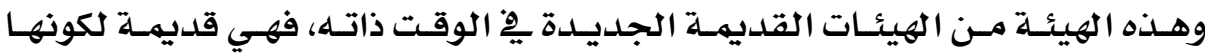

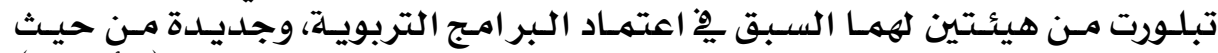

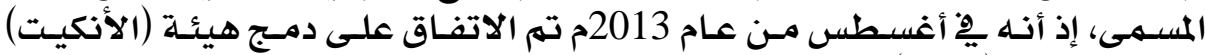

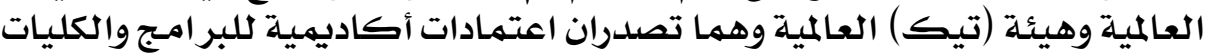

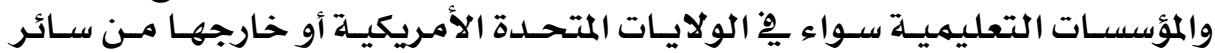

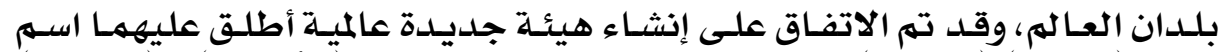

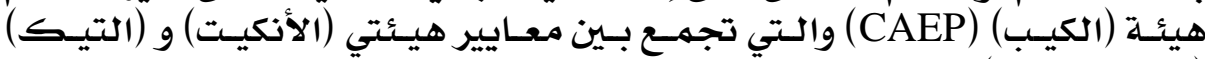
(العتيبي، (10) (10)

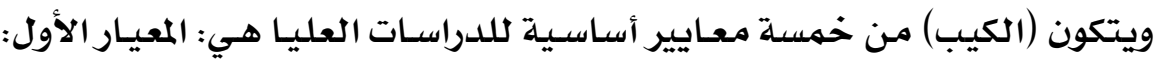

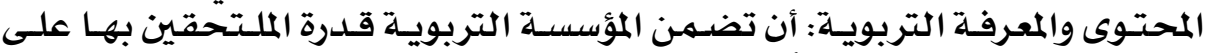

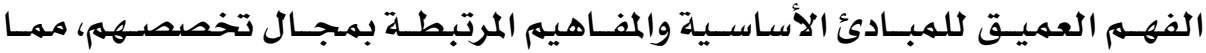

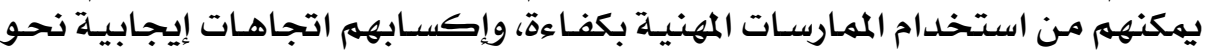

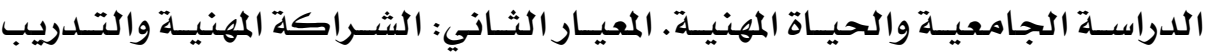

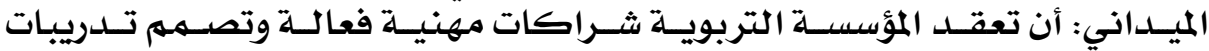

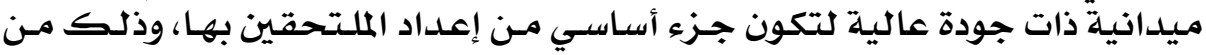

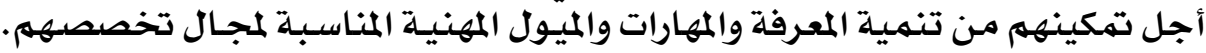

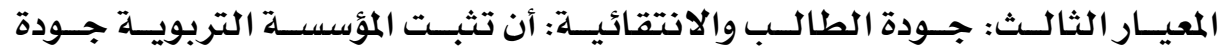

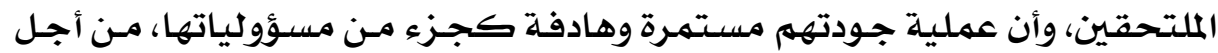

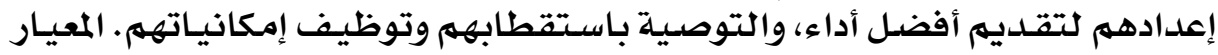

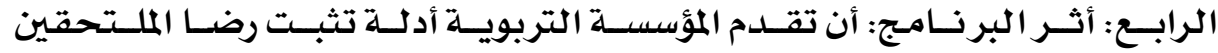

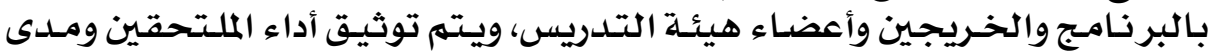

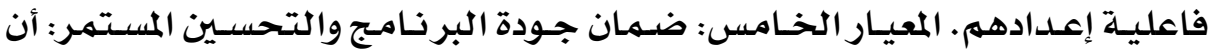

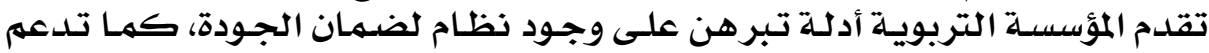

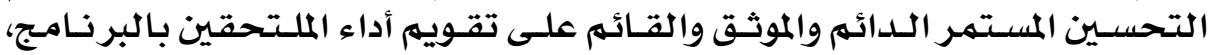

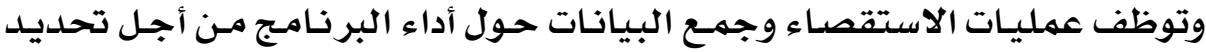




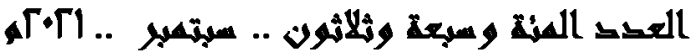

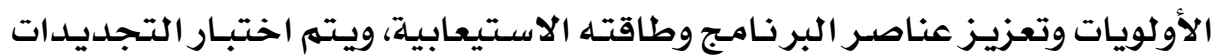

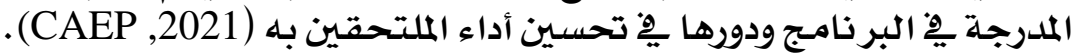

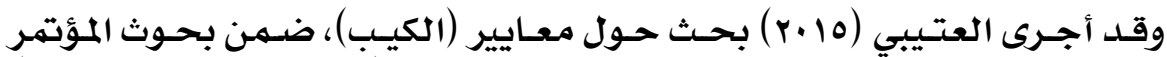

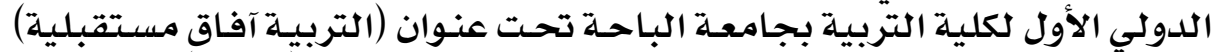

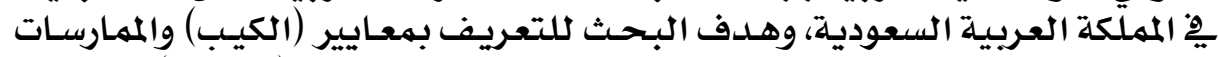

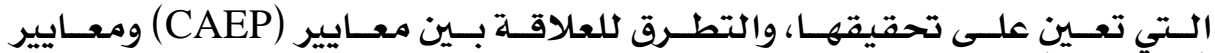

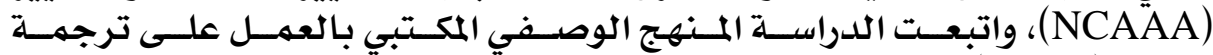

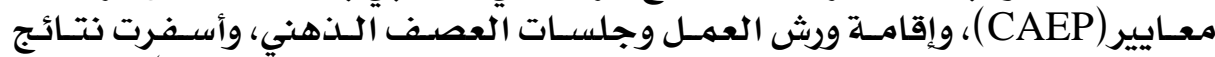

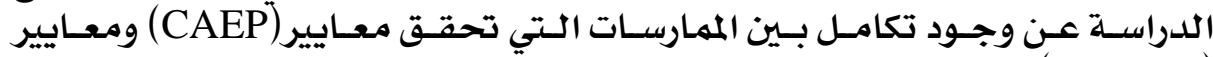

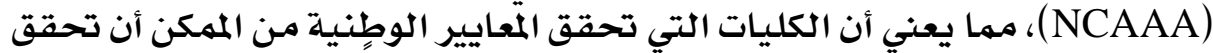

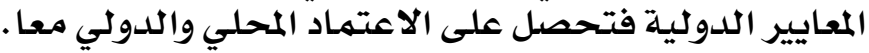

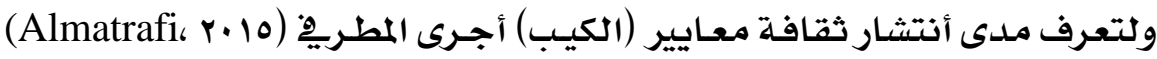

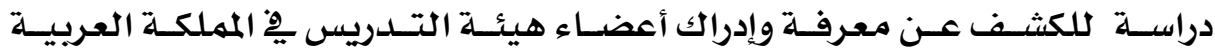

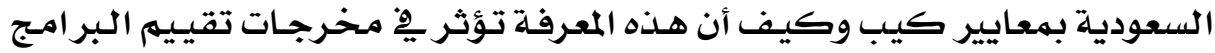

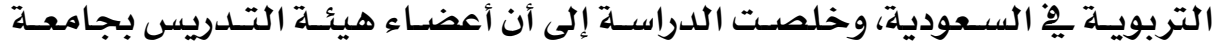

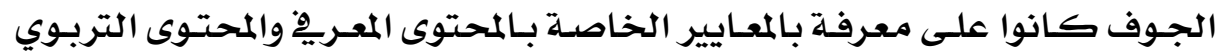

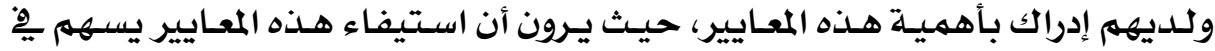

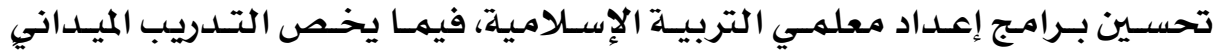

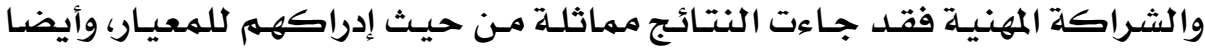

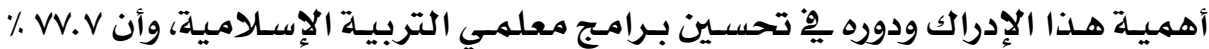

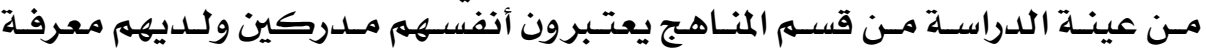

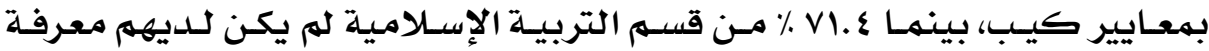

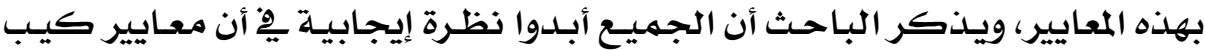

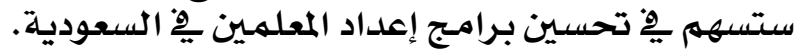

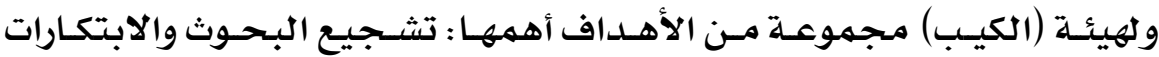

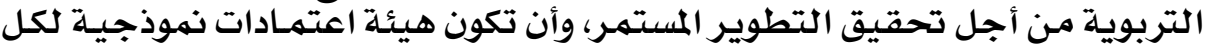

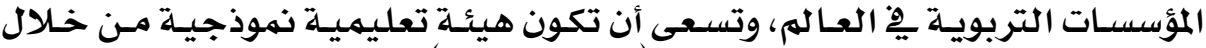

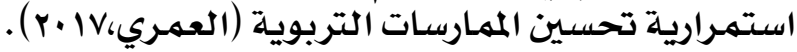

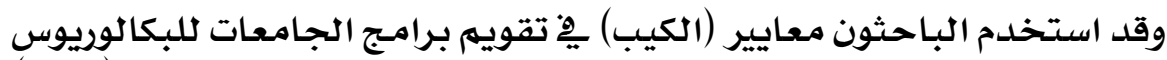

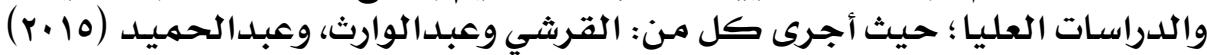

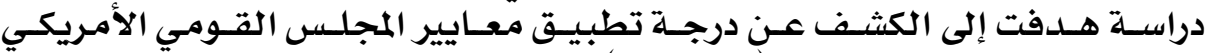

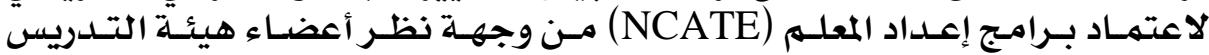

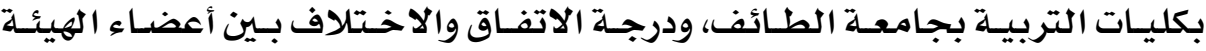

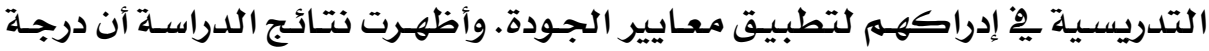

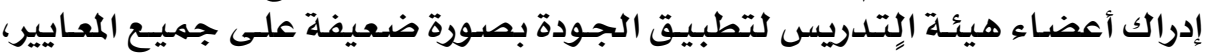

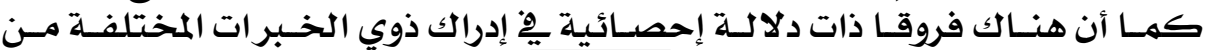




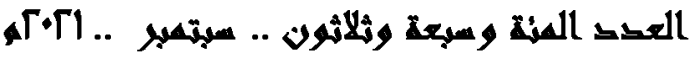

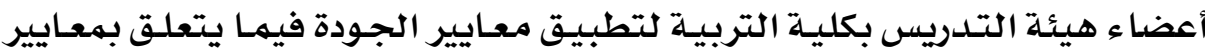

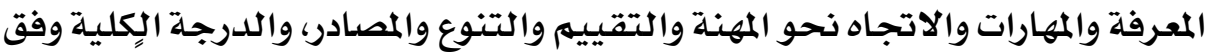

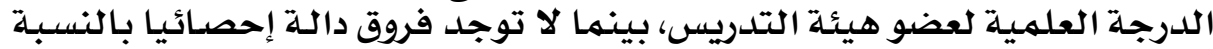

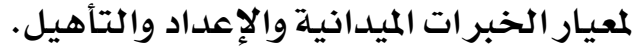

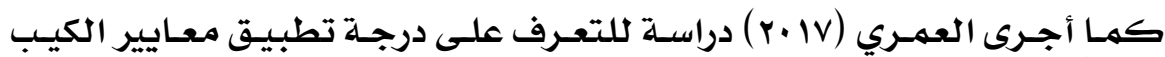

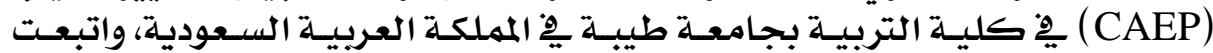

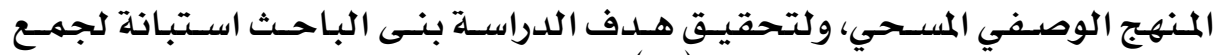

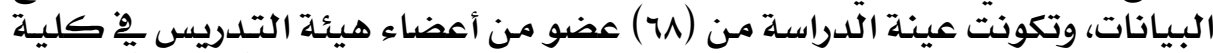

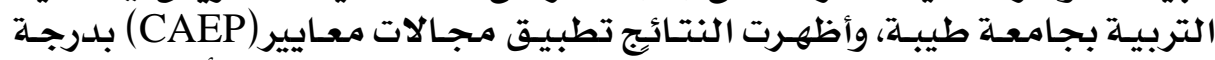

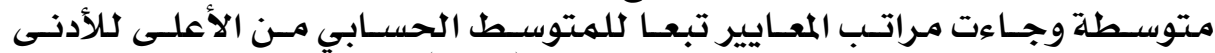

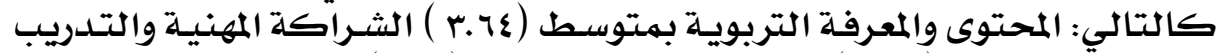

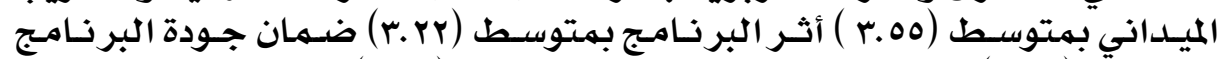

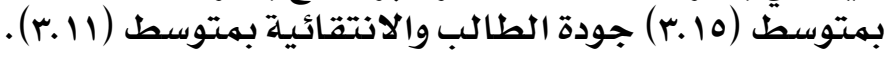

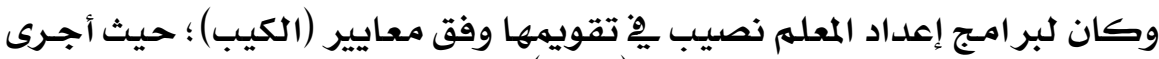

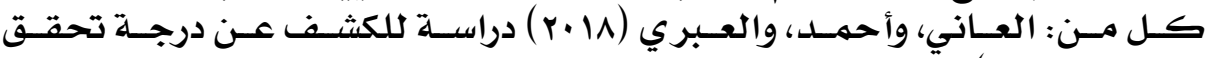

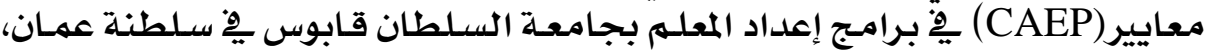

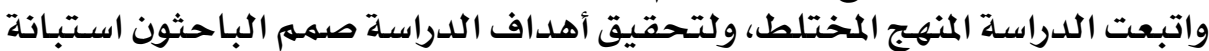

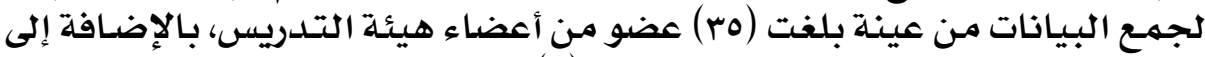

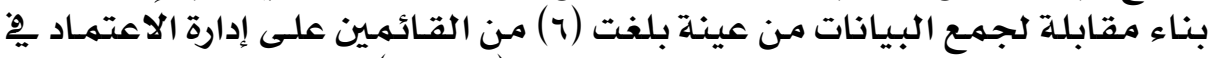

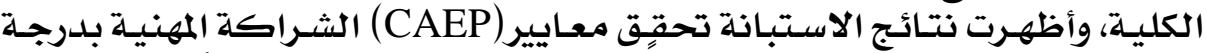

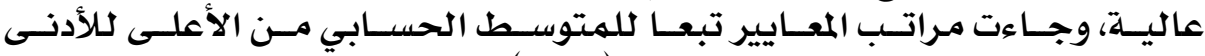

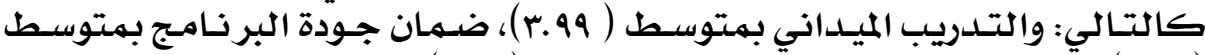

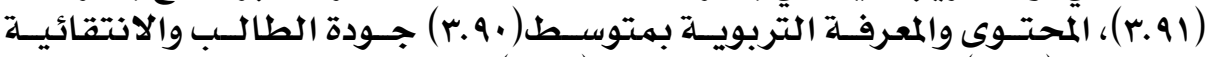

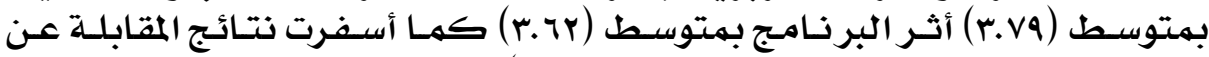

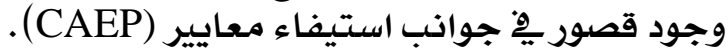

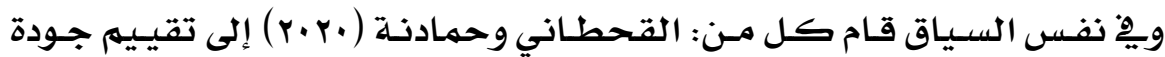

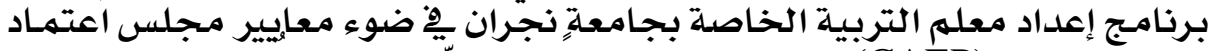

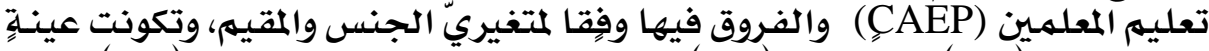

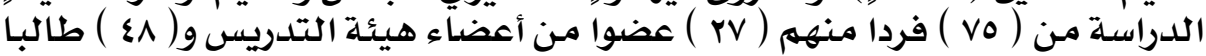

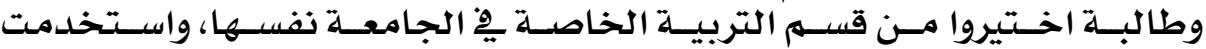

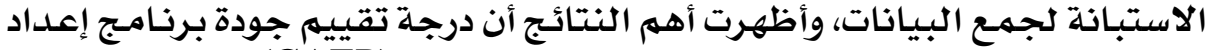

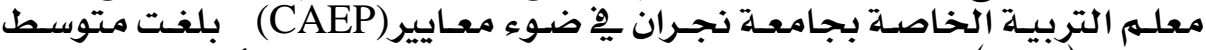

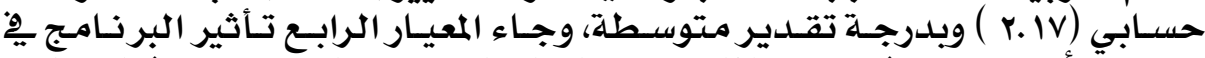

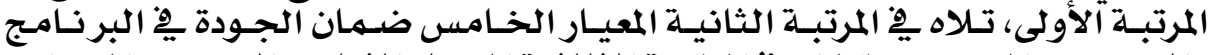

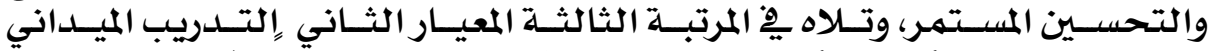

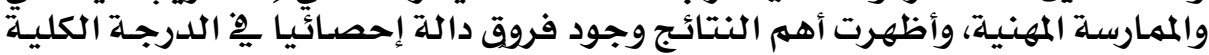

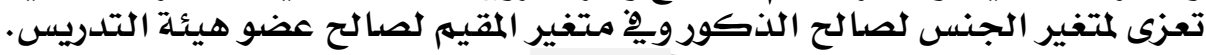




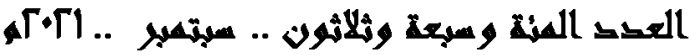

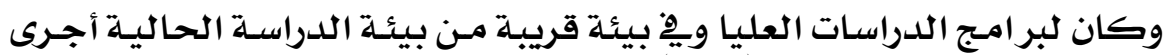

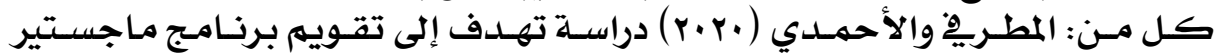

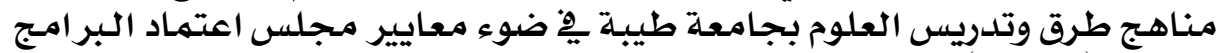

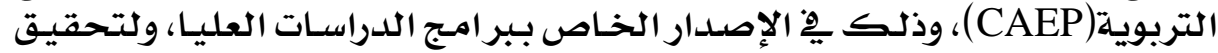

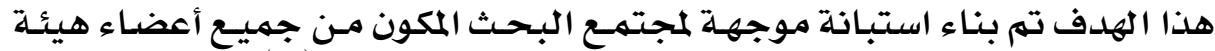

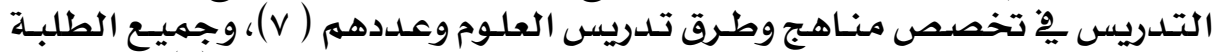

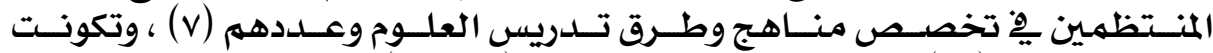

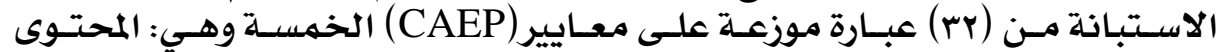

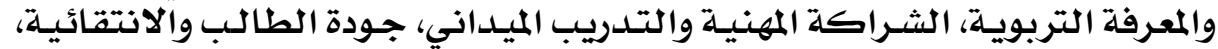

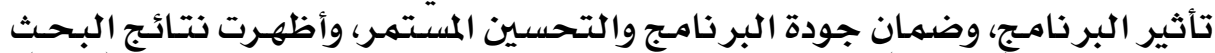

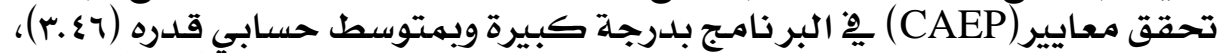

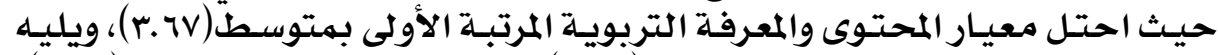

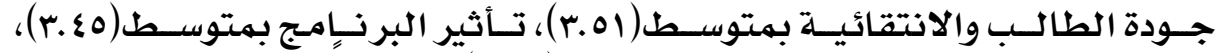

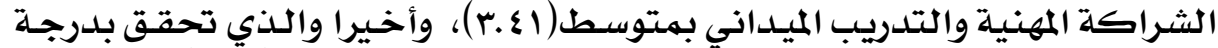

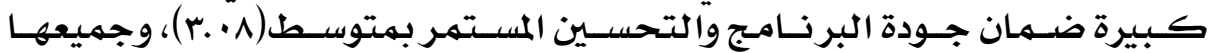

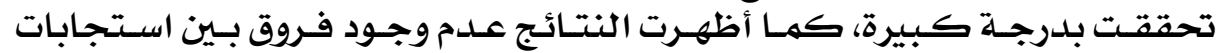

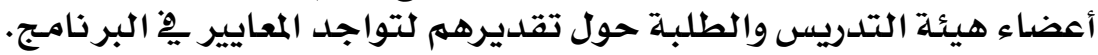

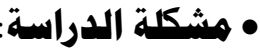

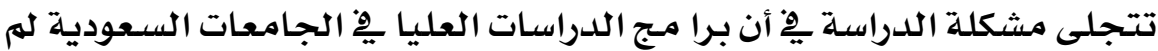

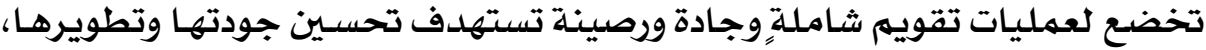

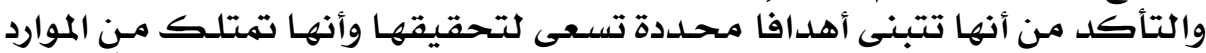

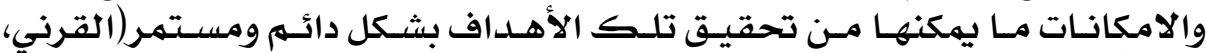
. ( r. Ir

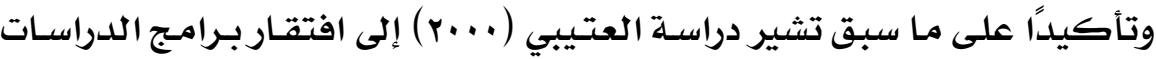

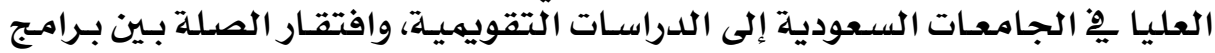

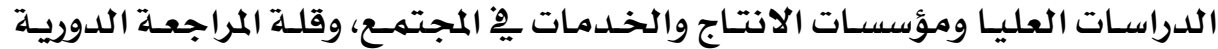

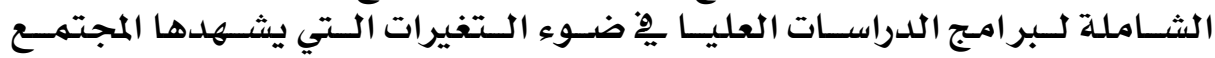
السعودي.

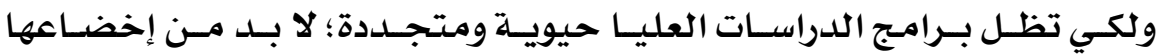

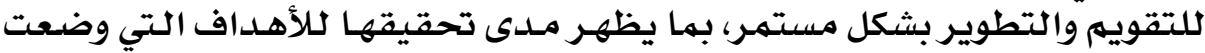

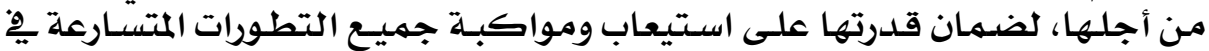

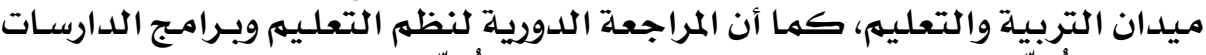

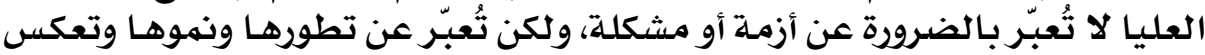

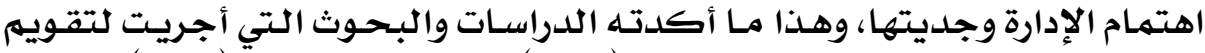

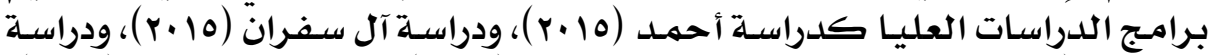

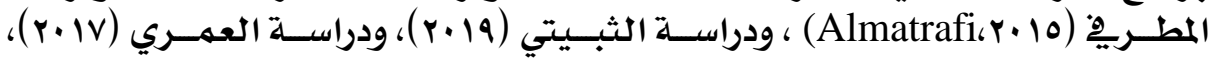




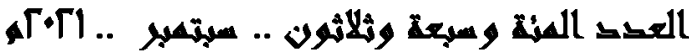

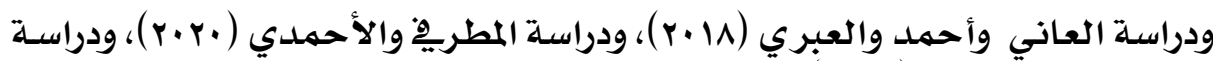

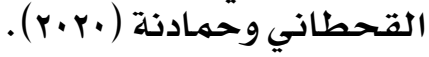

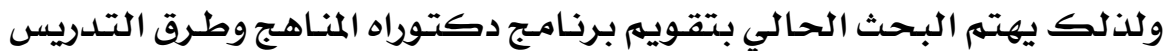

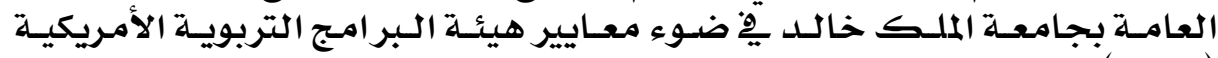

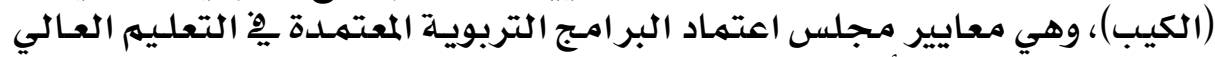

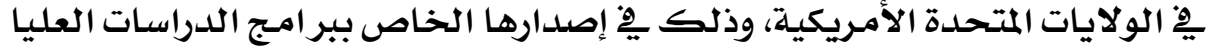
تعلئ (Council for the Accreditation of Educator Preparation)

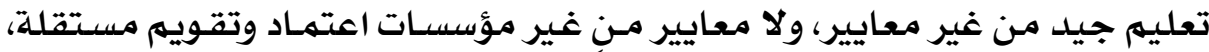

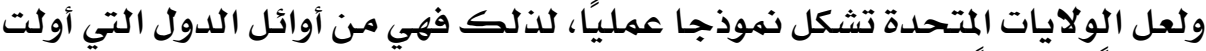

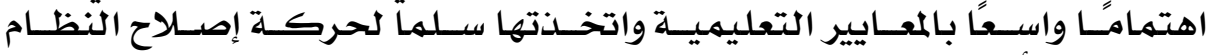

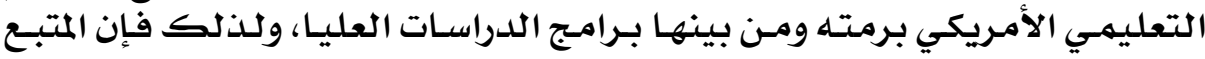

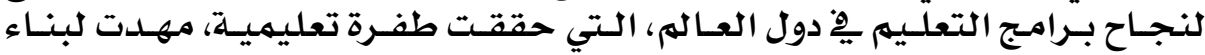

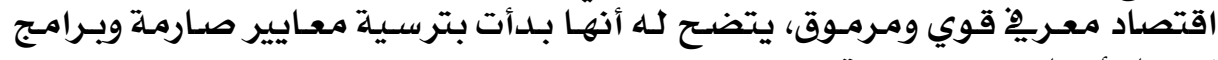

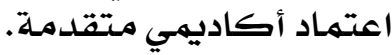

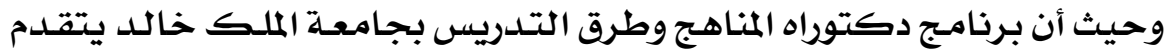

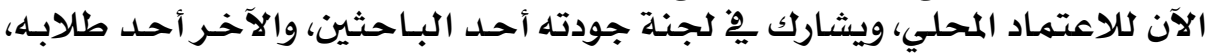

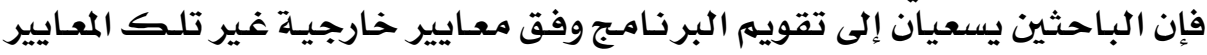

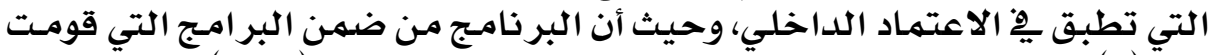

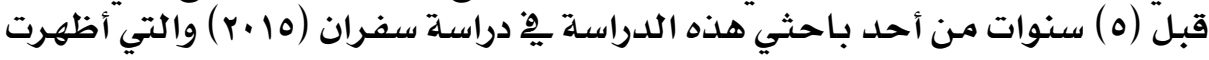

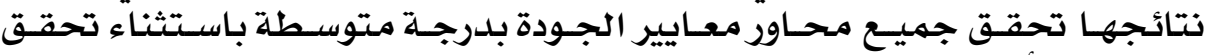

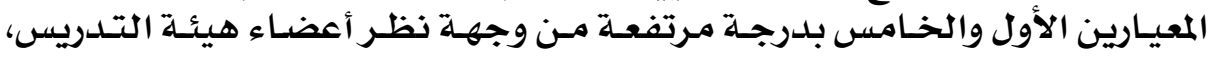

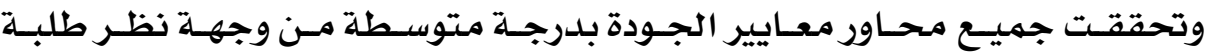

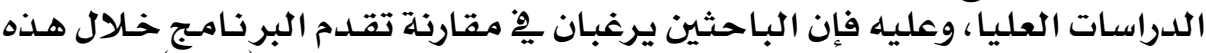

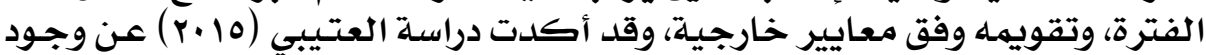

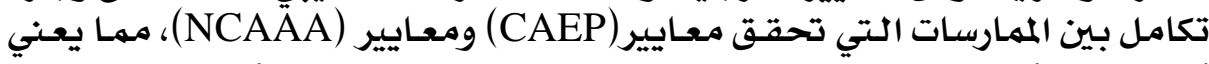

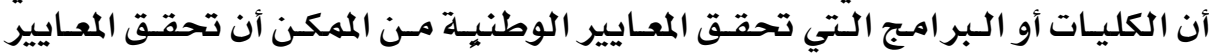

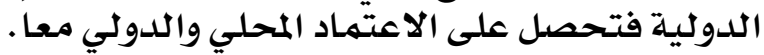

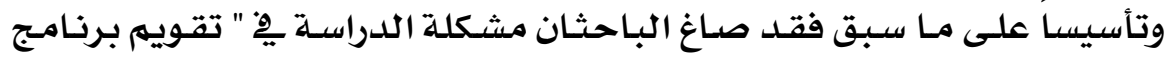

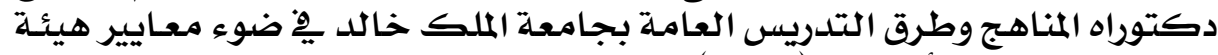

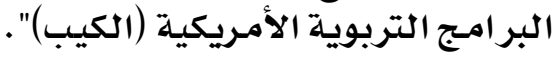

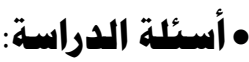
تجيب الدراسة عن السؤال الرئيس الآتي:

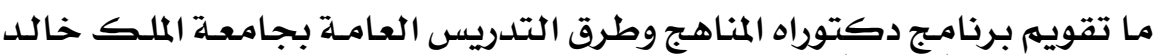

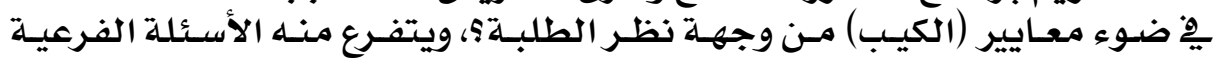
الآتية: 


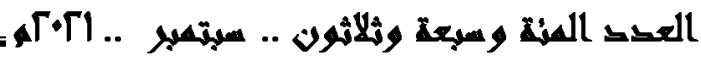

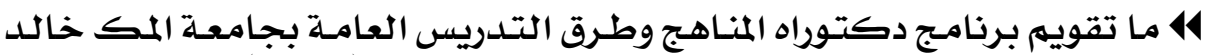

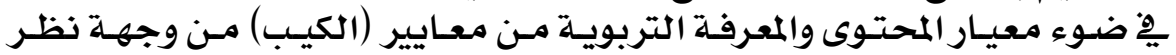
الطلبـة ماءو

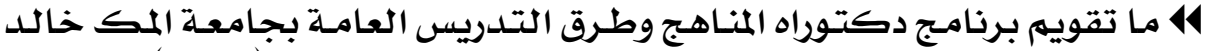

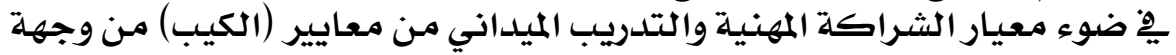
نظر الطلبـة

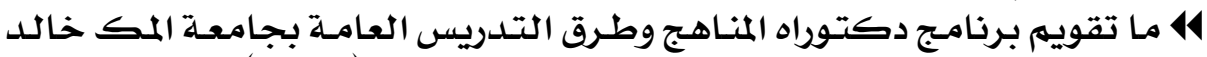

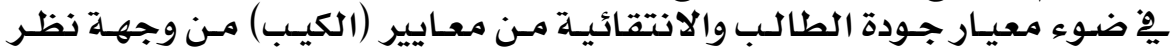
الطلبـة ماء

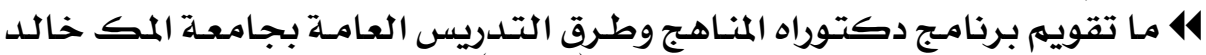

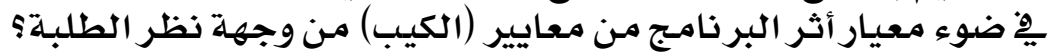

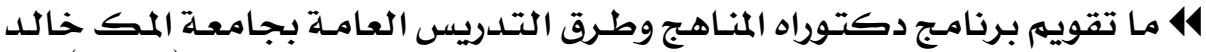

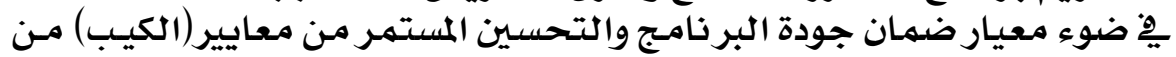

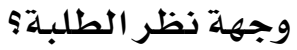

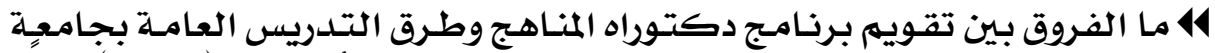

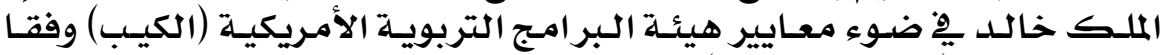
لمتغير الجنس (طلاب/ طالبات) ؟ • أهداف الدراستة:

تهلدف الدراسـة إذى التىالى

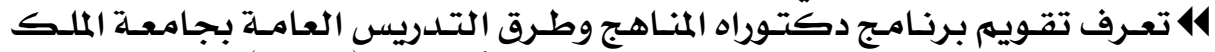

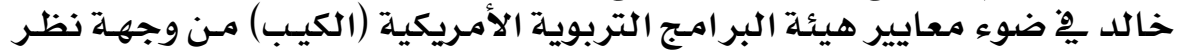

14 تعـرف الطلبـة.

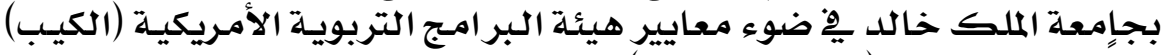

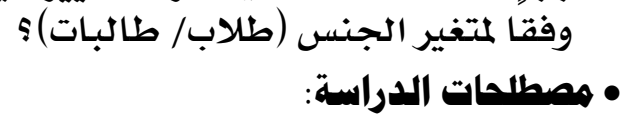
• هيئة البراهج التربوية الأهريكية (الكيب):

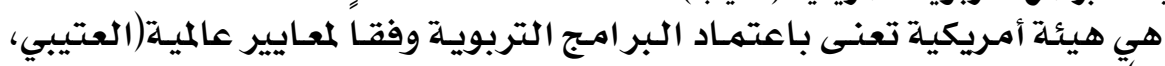
. (r.10

• تقويم البراهمج التعليميية:

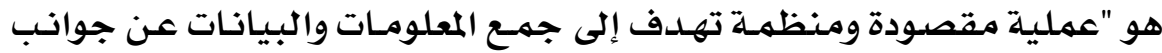

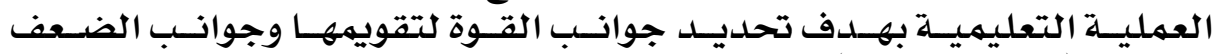

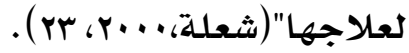

• تقويم برناهج دكتوراه المناهج وطرق التدريس العاهة:

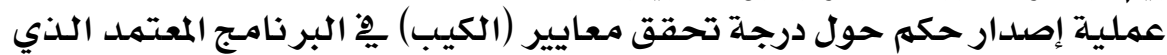

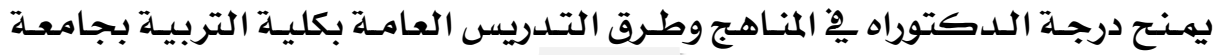




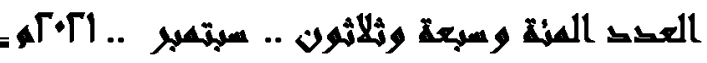

الملك خالد بنظام الرسالة والمقررات، ومعرفة الفروق وفقًا لمتغير الجـنس(طلاب/

طالبـات).

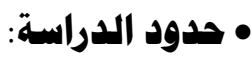

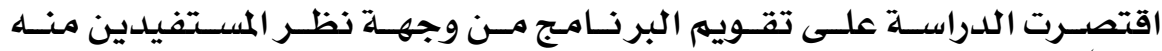

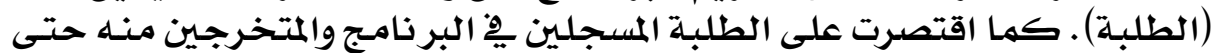

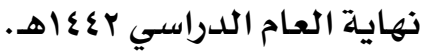

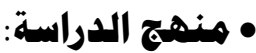

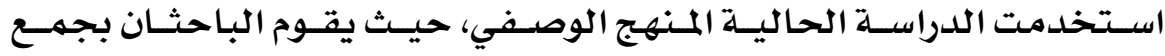

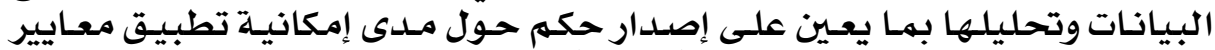

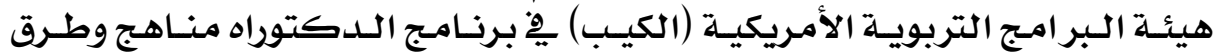
التدريس العامـة بجامعة الملكئك خـالد.

• الطريقة والاجراءات:

• همتميمع الدراسة:

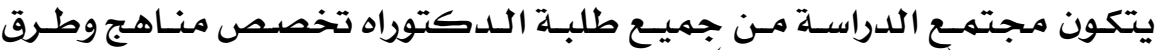

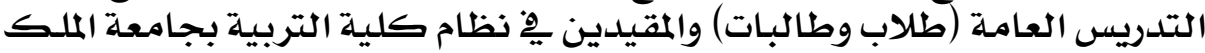

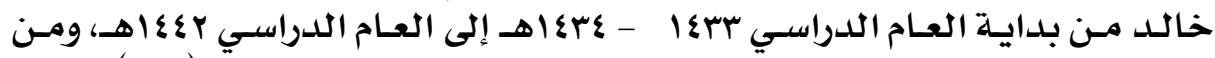

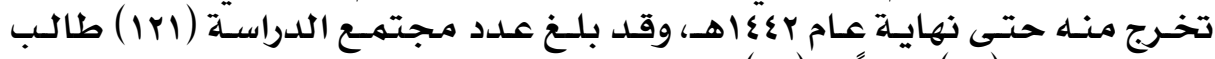

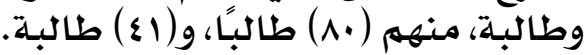

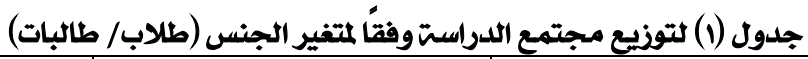

\begin{tabular}{|c|c|c|c|}
\hline النسبت & العدد & الجنس & م \\
\hline$\%$ & A. & طلاب & 1 \\
\hline$\%$ \% & \&1 & طالبات & $r$ \\
\hline \% & $|r|$ & المحموو & \\
\hline
\end{tabular}

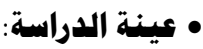

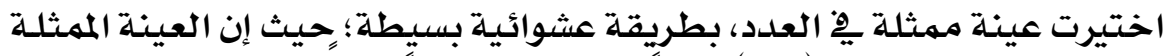

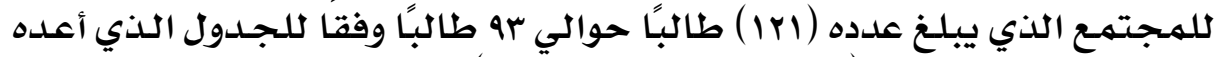

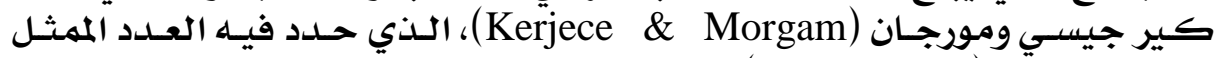

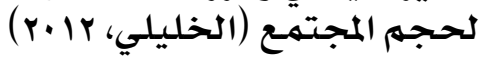

جلدول (r) لحجم العينت وفقًا لمتغير الجنس (طلاب/ (r) طالبات)

\begin{tabular}{|c|c|c|c|c|c|}
\hline نسبت العينت & عدد العينتة & النسبت & عدد المجتمع & الجنس & م \\
\hline$\%$ & IV & $\%$ & A. & طلاب & 1 \\
\hline \%rr & rI & $\%$ & \&1 & طالبات & $r$ \\
\hline$\%$ & 91 & $\%$ & $|r|$ & المجمووع & \\
\hline
\end{tabular}

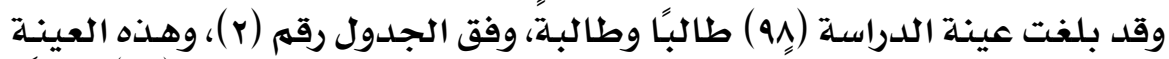

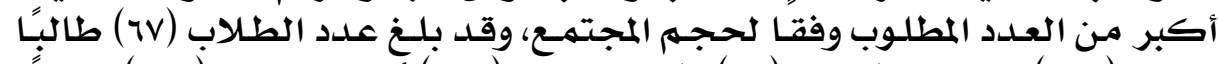

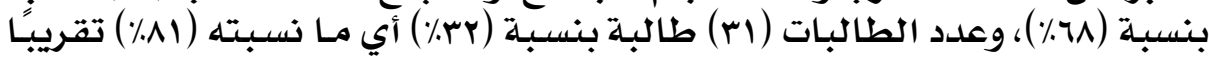
من حجم مجتهـع الدراسـة. 


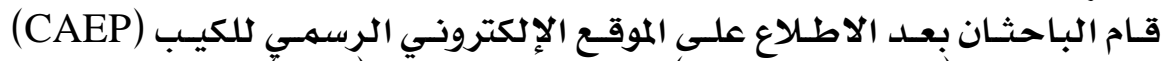

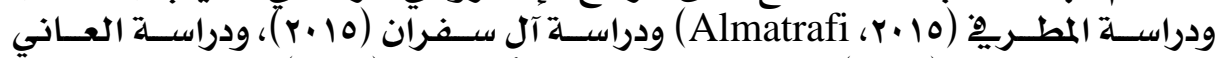

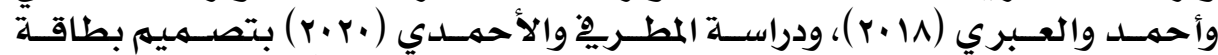

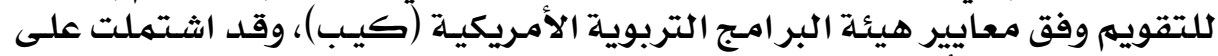

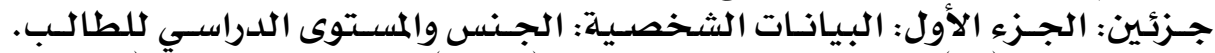

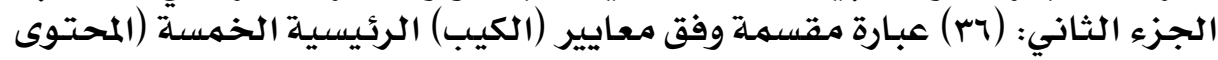

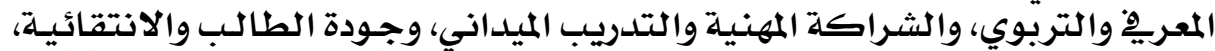

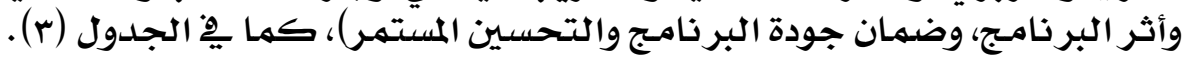
جدول (r) توزيع العبارات على المعايير فو صورتها الأوليت

\begin{tabular}{|c|c|c|}
\hline عدد العبارات & المعيار & م \\
\hline is & المحتوى والمعرفت التريويتً & 1 \\
\hline 1 & الشراكت المهنيتيت والتدريب الميداني & $r$ \\
\hline$\Lambda$ & جودة الطالب والانتقائية & $r$ \\
\hline$\varepsilon$ & أثر البرنامج & $\varepsilon$ \\
\hline 0 & ضمان جودة البرنامج والتحسين المستم & ○ \\
\hline$r$ & مجموع العبارات & \\
\hline
\end{tabular}

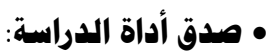

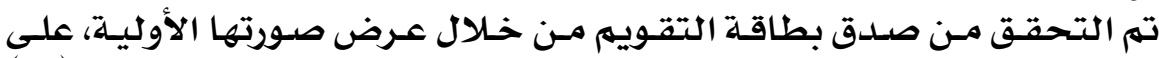

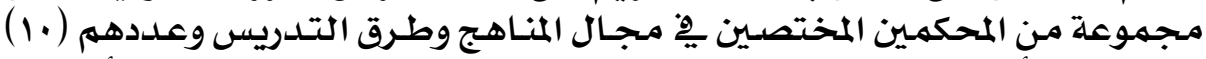

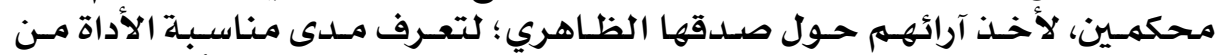

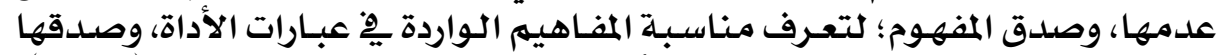

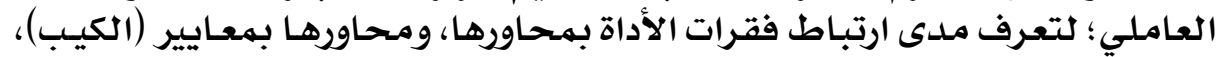

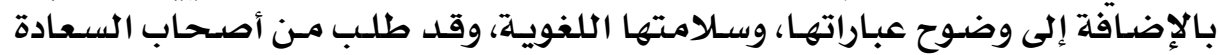

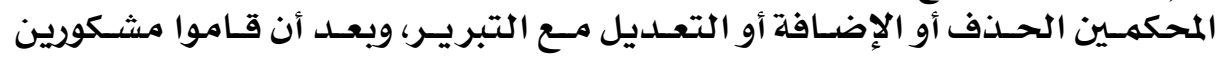

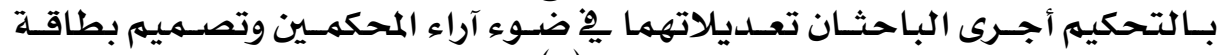

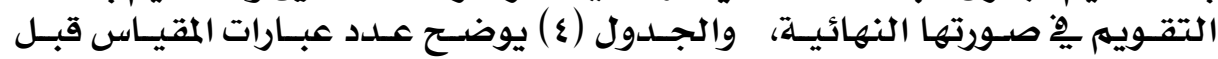

التحكيهم وبعده.

\begin{tabular}{|c|c|c|c|c|c|}
\hline عدد العبارات التي & عدد العبارات & عدد العبارات & عدد العبارات & قدب التباركيم & رقم المحود \\
\hline 7 & . & 1 & ir & ir & 1 \\
\hline 1 & - & 1 & 0 & 7 & $r$ \\
\hline$r$ & . & 1 & $v$ & $\Lambda$ & $r$ \\
\hline 1 & 1 & - & 0 & $\varepsilon$ & $\varepsilon$ \\
\hline$r$ & 1 & . & 7 & 0 & 0 \\
\hline $1 \varepsilon$ & $r$ & $r$ & ro & T & المحموو \\
\hline
\end{tabular}

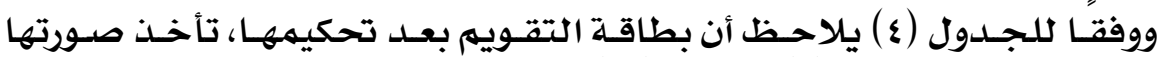

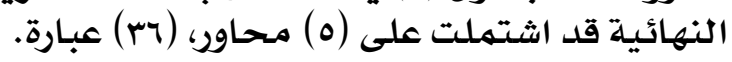




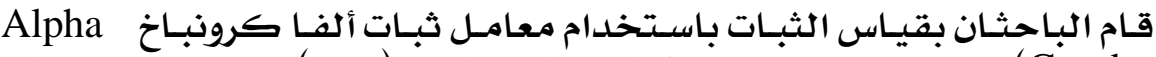

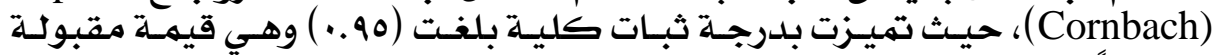

احصائيًا.

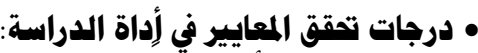

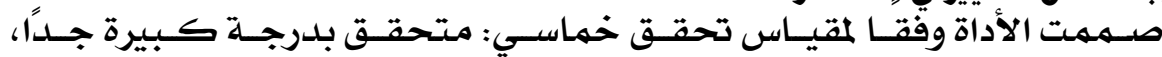

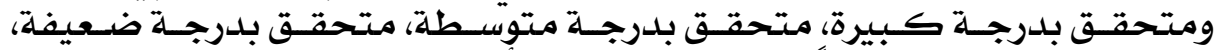

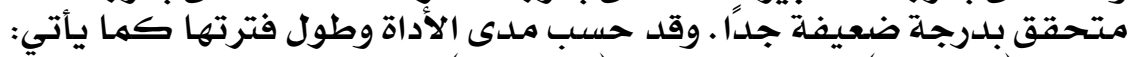

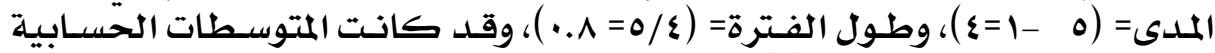

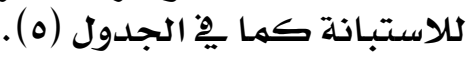

\begin{tabular}{|c|c|c|}
\hline 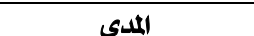 & 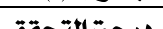 & \\
\hline من إلى أقل من •1.1. & كبيرة جذاً & 1 \\
\hline 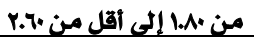 & كبيرة & $r$ \\
\hline من •T.r. إلى أقل من \&.ب & متوسطنة & $r$ \\
\hline من \&.r إلى أقل من r.\& & ضعيفت & $\varepsilon$ \\
\hline من •r.r إلى 0 & ضعيفتَجدًا & 0 \\
\hline
\end{tabular}

• • نتائج الدراسة ومناقشتها: • الإجابة عن السؤال الأول:

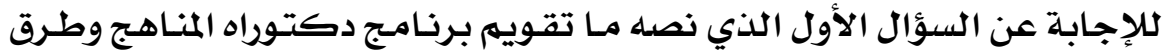

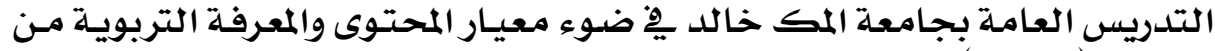

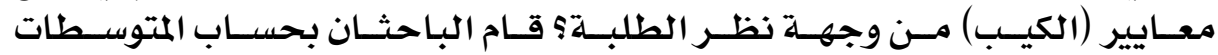

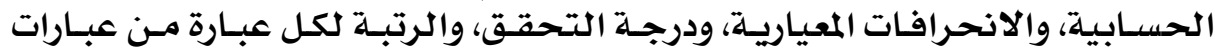

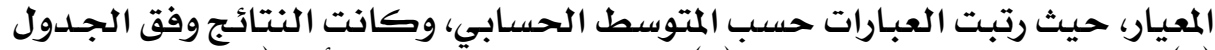

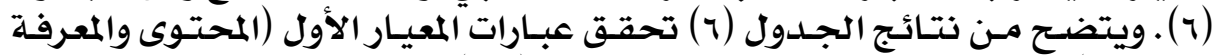

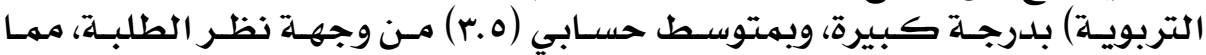

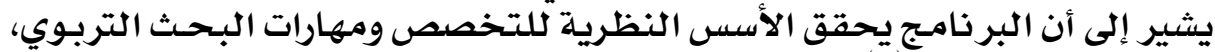

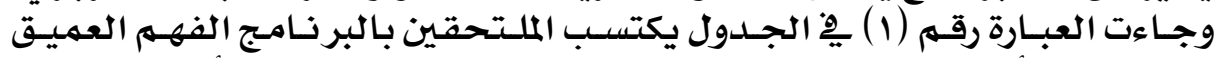

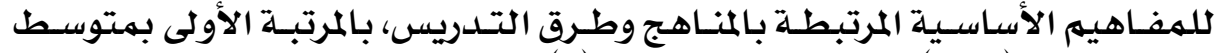

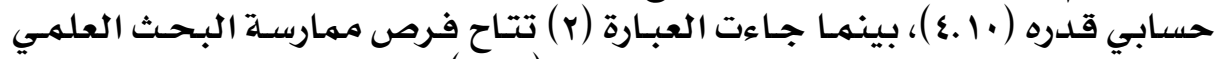

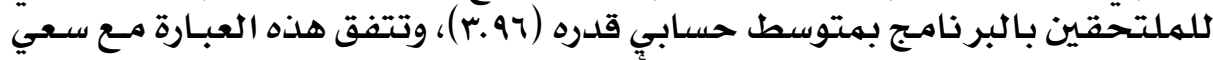

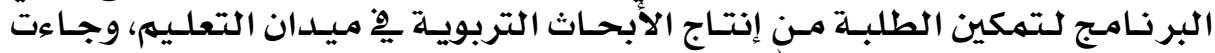

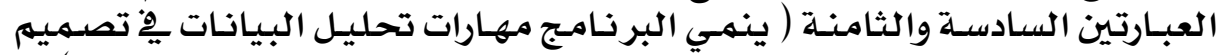

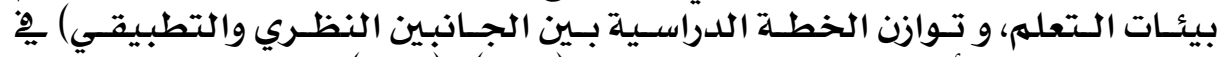

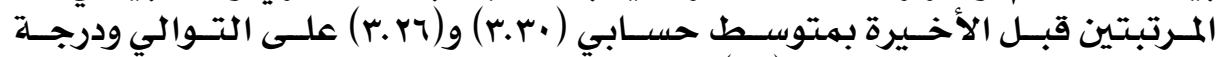

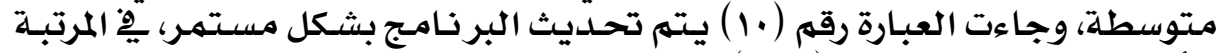

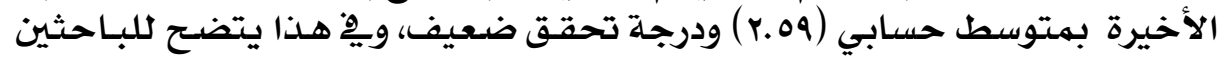

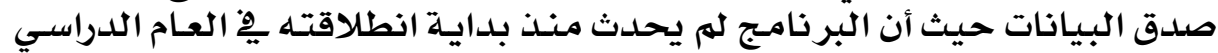




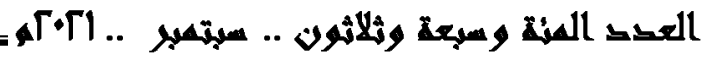

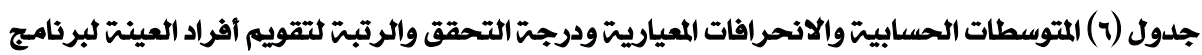
الدكتوراه يف ضوء معيار المحتوى والمعرفت التريويتي.

\begin{tabular}{|c|c|c|c|c|}
\hline الترتيب & التحقق & الانحياري & المتوسابي & العبارة \\
\hline الآول & كبيرة & $\cdot \cdot 11$ & 8.1. & 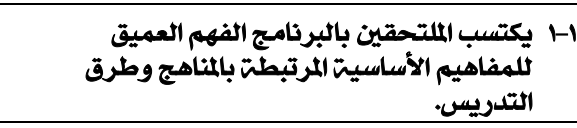 \\
\hline التاسابع: التاني & كبيرة كبيرة & $\begin{array}{l}. .91 \\
.41 \\
.049\end{array}$ & $\begin{array}{ll}r .99 \\
r . v 1 \\
r .81\end{array}$ & 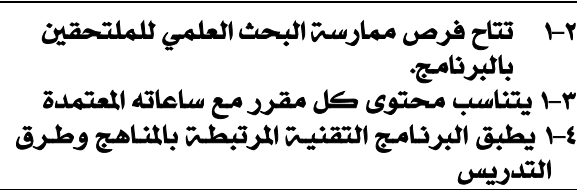 \\
\hline 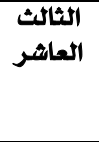 & متوسبيرة & .94 & $\begin{array}{l}\text { r.vई } \\
\text { r.r. }\end{array}$ & 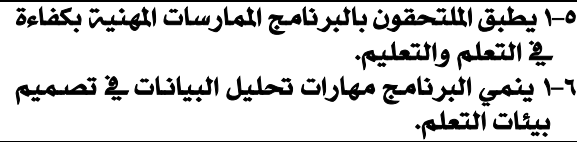 \\
\hline السابع & كبيرة & $1 . \%$ & r.80 & 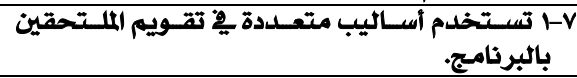 \\
\hline الخامس & متوسط & .99 & $\begin{array}{ll}r . r y \\
r .0\end{array}$ & 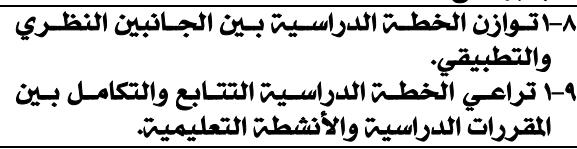 \\
\hline الثادئي & كبيرة & $\begin{array}{l}1.01 \\
.94 \\
1.4\end{array}$ & $\begin{array}{l}-r .09 \\
r .09 \\
r .21 \\
r .24\end{array}$ & 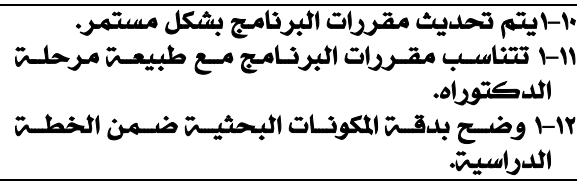 \\
\hline \multicolumn{2}{|c|}{ كبيرة } & .99 & r.o & المتوسط العام \\
\hline
\end{tabular}

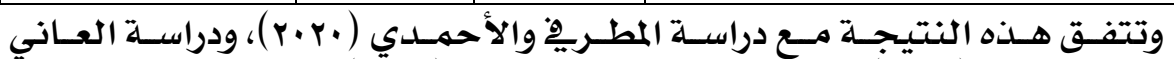

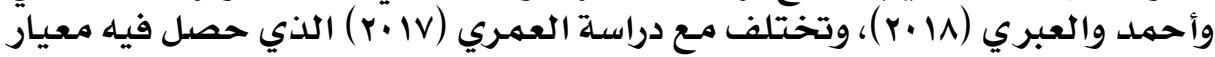

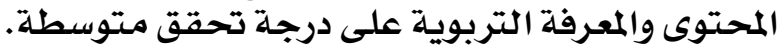

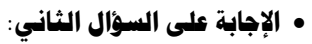

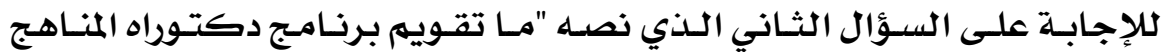

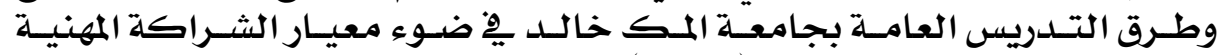

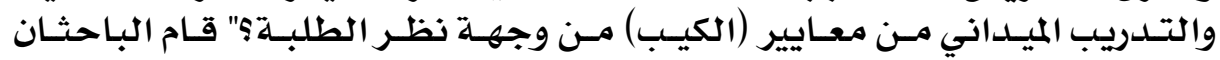

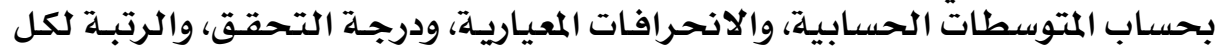

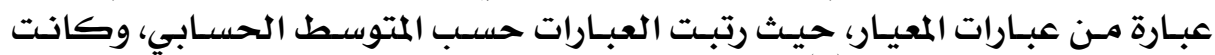

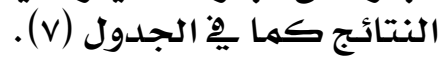

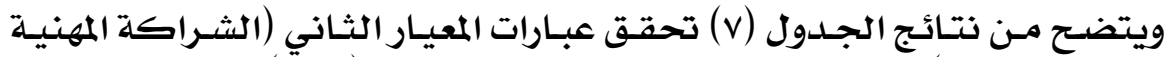

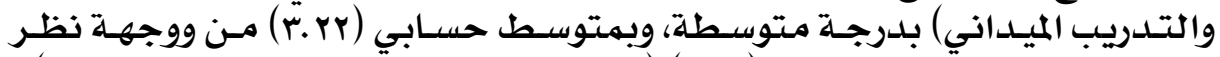

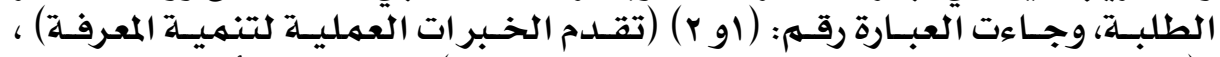

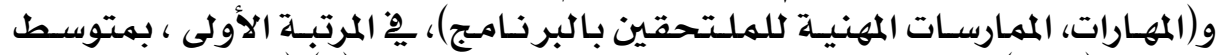

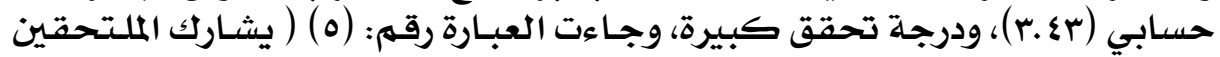




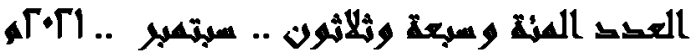

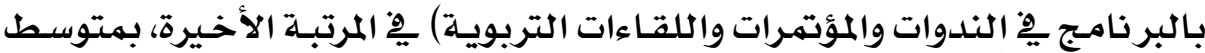

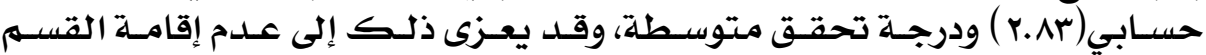

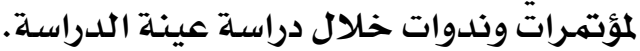

جدول (v) المتوسطات الحسابيت والانحرافات المعياريت ودرجت التحقق والرتبت لتتقويم أفراد العينت لبرنامج

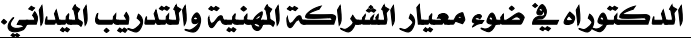

\begin{tabular}{|c|c|c|c|c|}
\hline الترتيب & التحقق & الانحيافي & المتوسطب & العبارة \\
\hline الأول & كبيرة & $\cdot \wedge 9$ & r.zr & 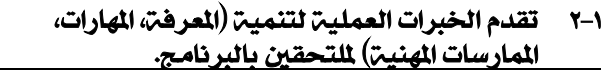 \\
\hline الرابع & متوسط & $\cdot \wedge 9$ & r.YE & 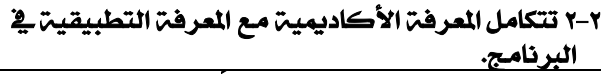 \\
\hline الثاني & متوسط & $\because A 1$ & r.ru & 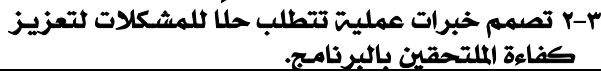 \\
\hline الثالث & متوسط & .94 & r.rV & 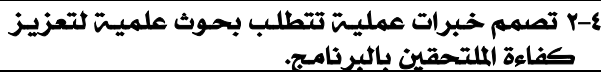 \\
\hline الخامس & متوسط & 1.4 & r.Ar & 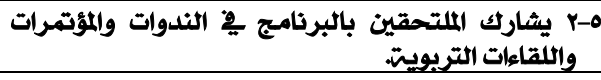 \\
\hline \multicolumn{2}{|c|}{ متوسط } & .90 & r.YY & المتوسط العام \\
\hline
\end{tabular}

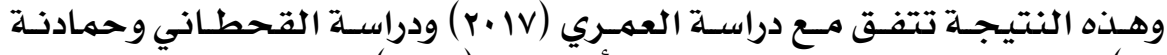

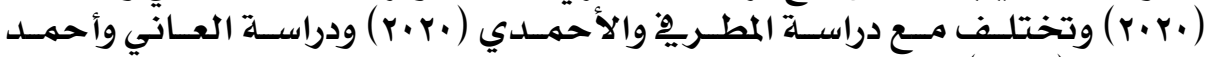

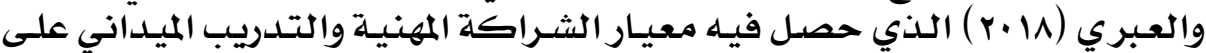
درجة تحقق كبيرة. • • بالإبة على السؤال الثالث:

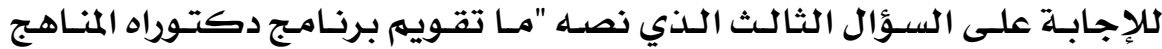

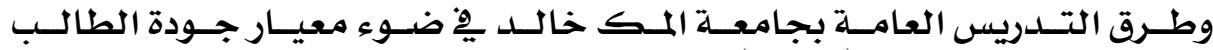

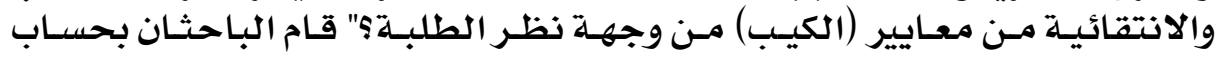

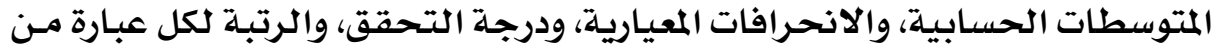

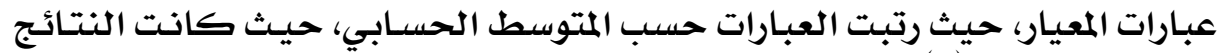

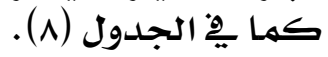

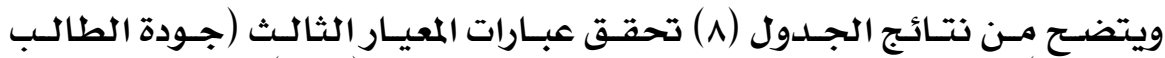

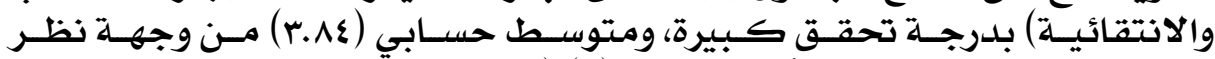

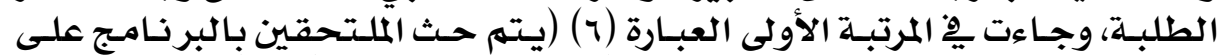

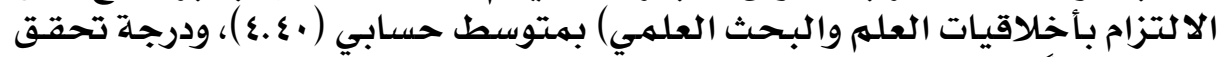

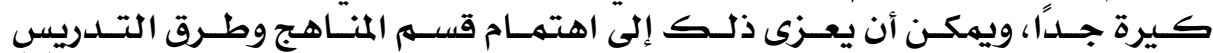

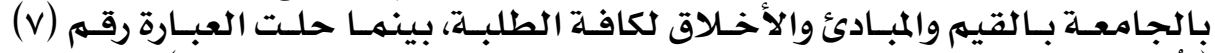

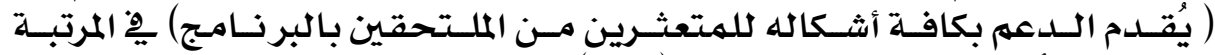

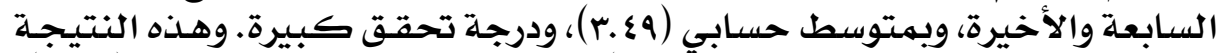

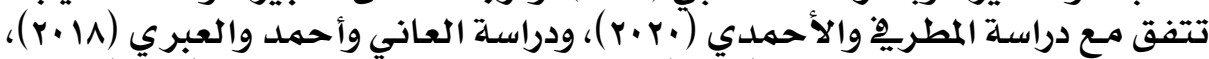

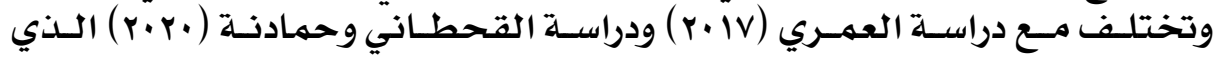

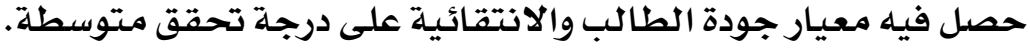

\section{$\varepsilon \cdot \boldsymbol{r}$}




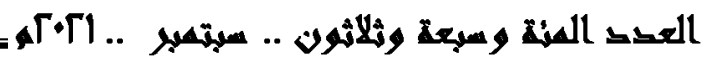

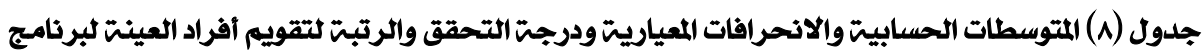

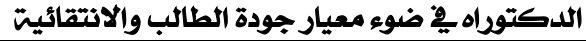

\begin{tabular}{|c|c|c|c|c|}
\hline الترتيب & التحقت & الالمعياراف & المتوسطابي & العبارة \\
\hline السادس & كبيرة & L.YY & r.or & 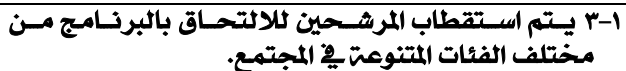 \\
\hline الثاني & كبيرة & $\cdot A Y$ & \&.Y. & 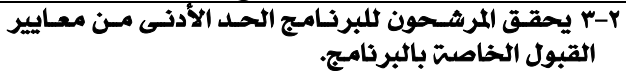 \\
\hline الخامس & كبيرة & $.9 \mathrm{~V}$ & r.\%* & 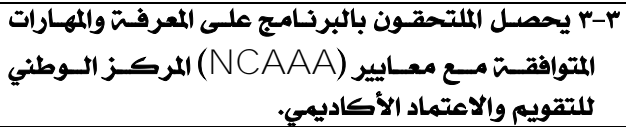 \\
\hline الثالث & كبيرة & 1.4 & $\varepsilon$ & 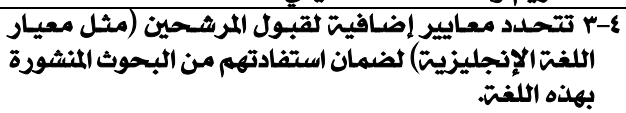 \\
\hline الرابع & كبيرة & .90 & r.th & 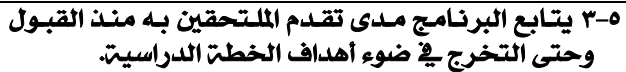 \\
\hline الأول & كبيرة & $\cdot . v 4$ & \&.\&. & آلعلم والبحث اللمتحقين بالبرنامج على الالتزام باخلاقيات \\
\hline السابع & كبيرة & $.4 \varepsilon$ & $r . \$ 9$ & 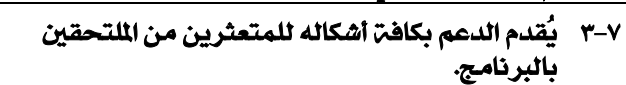 \\
\hline \multicolumn{2}{|c|}{ كبيرة } & $1 . r . r$ & $r \cdot \wedge \varepsilon$ & المتوسط العام \\
\hline
\end{tabular}

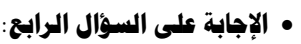

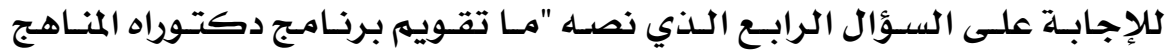

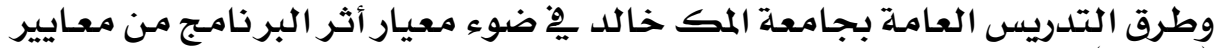

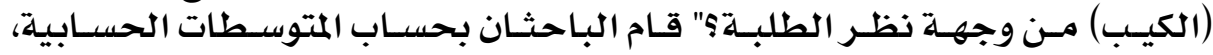

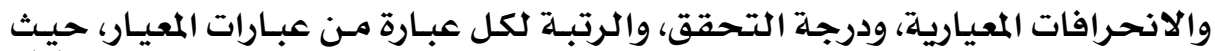

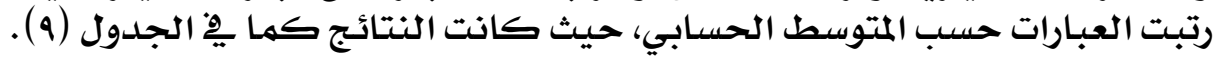

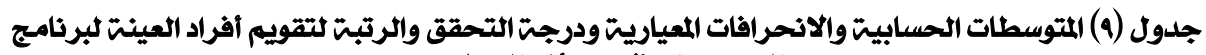

\begin{tabular}{|c|c|c|c|c|}
\hline \multicolumn{5}{|c|}{ درجت } \\
\hline المرنيب & التحقق & المعياري & الحسابي & العبارة \\
\hline الثاني & كبيرة & $1.1 \%$ & r.07 & 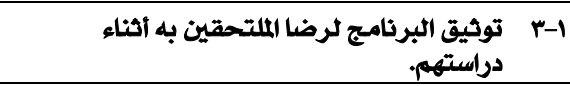 \\
\hline الثالث & كبيرة & .94 & r.oq & 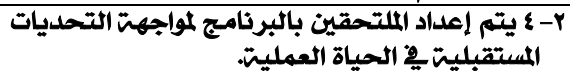 \\
\hline الأول & كبيرة & $\because . v 7$ & r.97 & 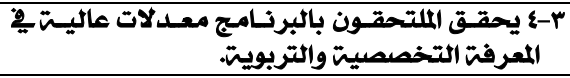 \\
\hline الرابع & متوسط & 1.14 & r.11 & 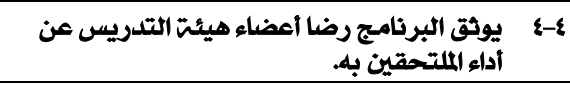 \\
\hline الخامس & متوسط & L.YT & Y.TY & 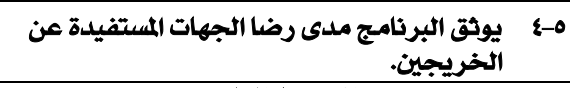 \\
\hline & & 1.17 & r.rv & المتوسط العام \\
\hline
\end{tabular}

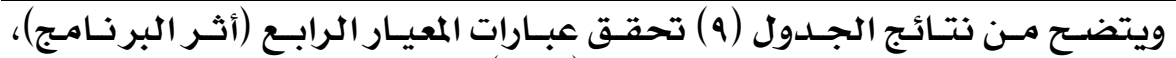

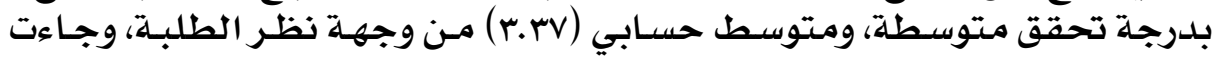




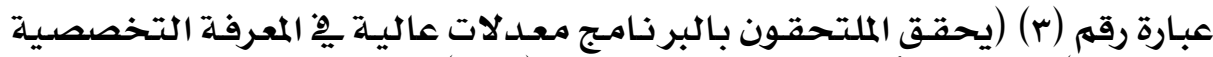

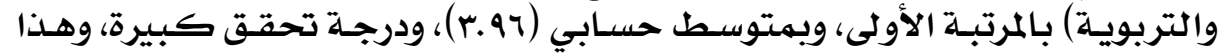

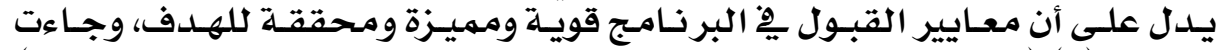

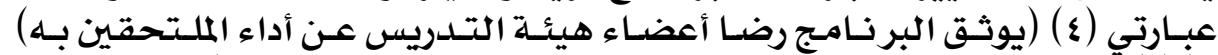

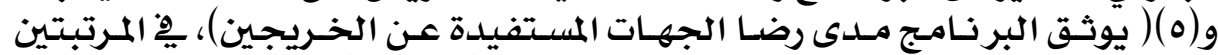

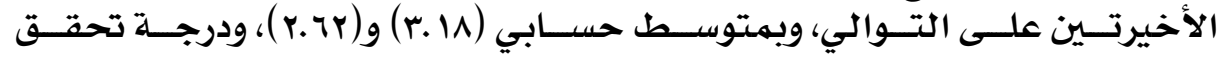

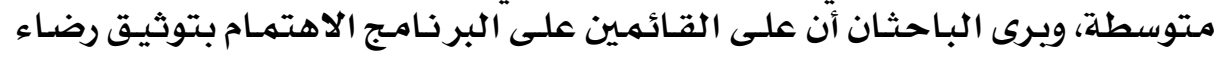

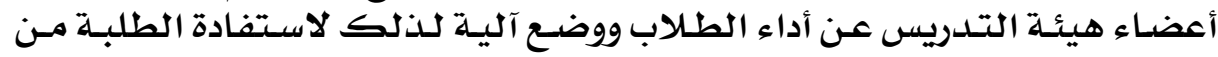

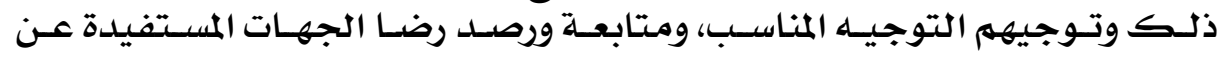
الخريجين. ذبكوجين.

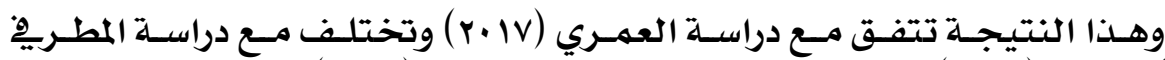

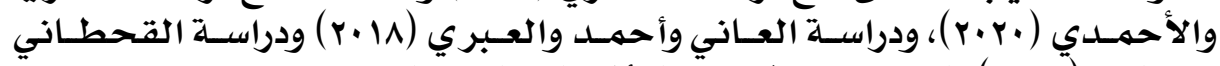

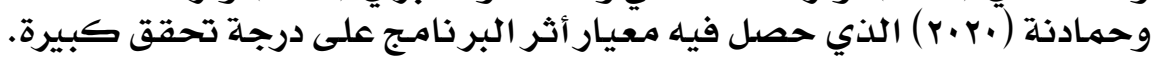

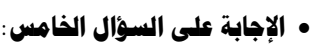

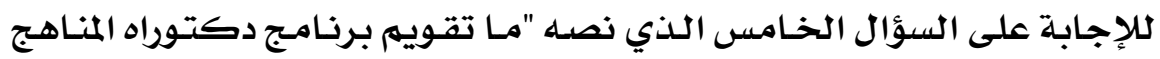

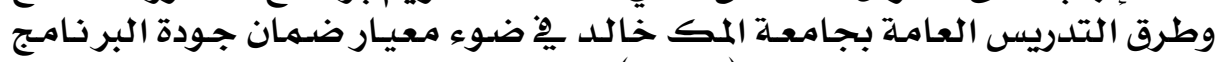

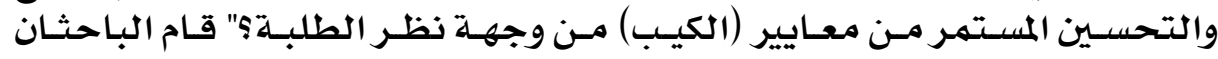

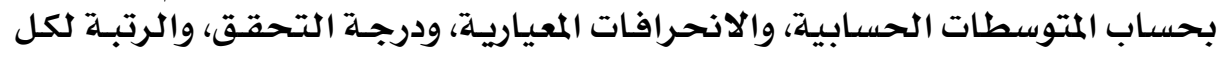

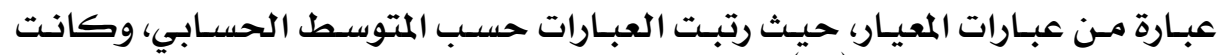

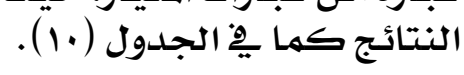

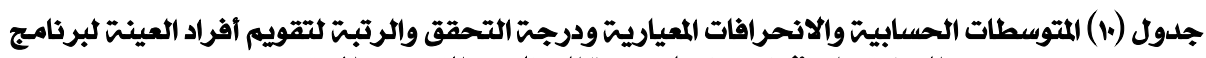

\begin{tabular}{|c|c|c|c|c|}
\hline الترتيب & درجـتحة & الانحعيــراف & المتوســـــ الحسابي & العبارة \\
\hline الأول & كبيرة & $.9 \cdot$ & r.TV & 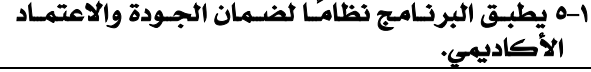 \\
\hline الثاني & كبيرة & .90 & r.\&. & 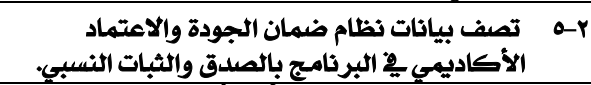 \\
\hline الرابع & متوسط & $1.1 \%$ & r.qV & 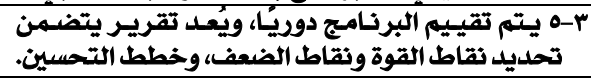 \\
\hline 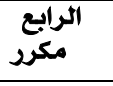 & متوسط & 1.46 & r.qv & 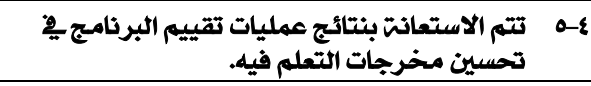 \\
\hline الخامس & ضعيف & 1.10 & r.17 & 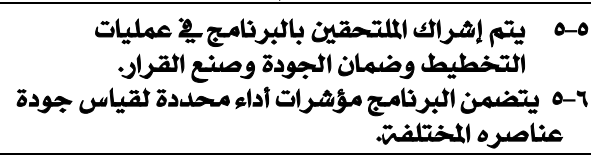 \\
\hline & متوسط & 1.18 & $r+\varepsilon$ & المتوسط العام \\
\hline
\end{tabular}

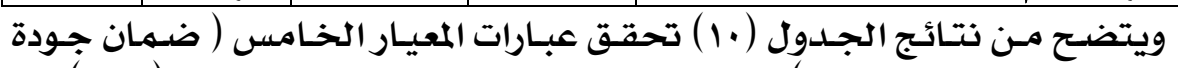

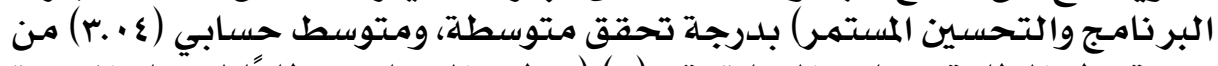

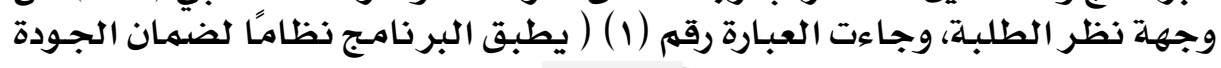

\section{$\varepsilon \cdot \theta$}




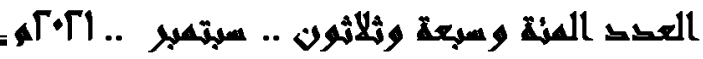

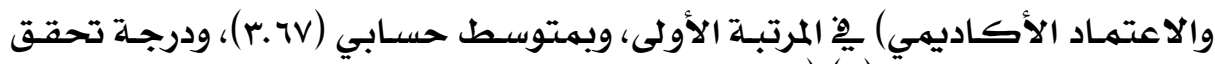

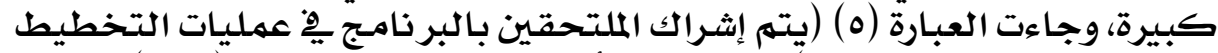

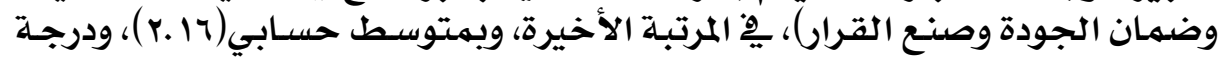

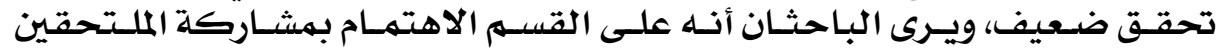

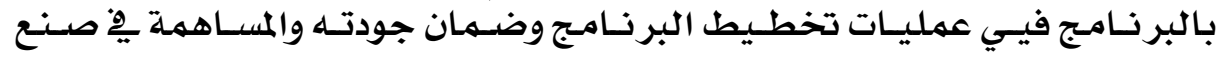
القرار.

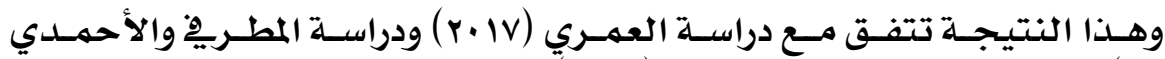

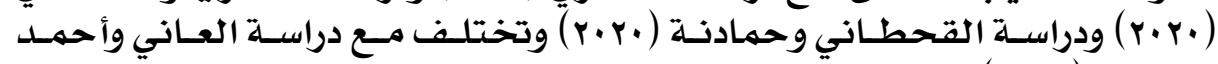

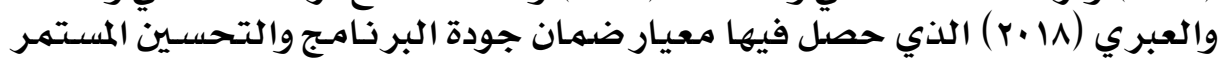

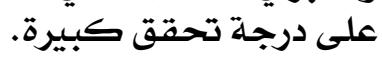

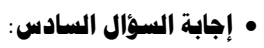

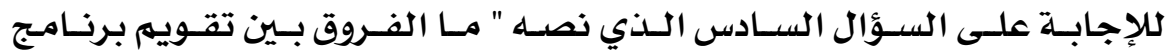

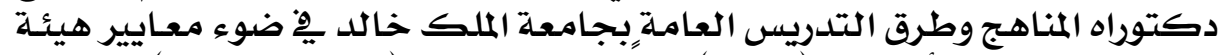

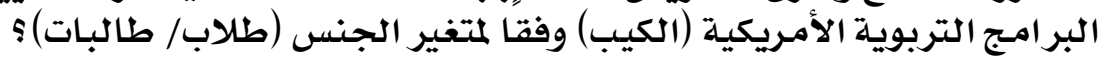

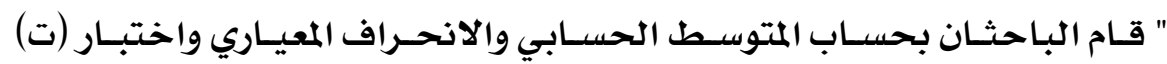

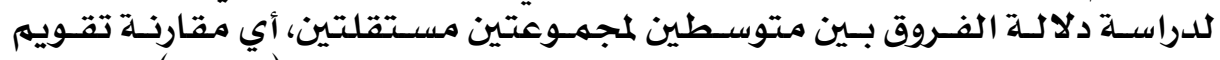

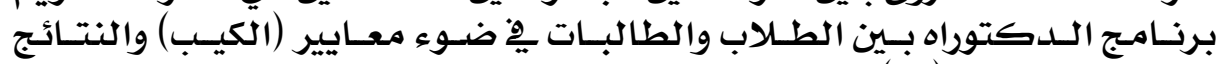

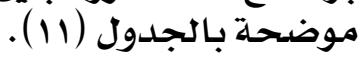

جدول (11) يوضح الاستجابات المتعلقت بالفروق بين الطلاب والطالبات.

\begin{tabular}{|c|c|c|c|c|c|c|}
\hline 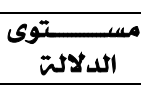 & فيمست & الانحياري_ــراف & 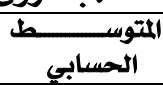 & $\dot{ن}$ & آلجنس & المعايير \\
\hline \multirow[b]{2}{*}{0.512} & \multirow{2}{*}{0.755} & 0.907 & 3.54 & 6 & طلاب & \multirow[t]{2}{*}{ ا- المحتوى والمعرفت التربوية } \\
\hline & & 0.96 & 3.47 & 31 & طالبات & \\
\hline \multirow{2}{*}{ iv. } & \multirow{2}{*}{1.07} & 0.895 & 3.33 & 6 & طلاب & \multirow{2}{*}{ r- الشراكت المهنيت والتدريب } \\
\hline & & 0.973 & 3.006 & 31 & طالبات & \\
\hline \multirow[b]{2}{*}{0.065} & \multirow[b]{2}{*}{2319} & 0.929 & 3.99 & 6 & طلاب & \multirow[t]{2}{*}{ r- جودة الطالب والانتقائيت } \\
\hline & & 0.945 & 3.55 & 31 & طالبات & \\
\hline \multirow[b]{2}{*}{0.321} & \multirow[b]{2}{*}{1.353} & 1068 & 3.47 & 67 & طلاب & \multirow[t]{2}{*}{ ع- تاثير البرنامج } \\
\hline & & 0.998 & 3.167 & 31 & طالبات & \\
\hline \multirow[b]{2}{*}{0.551} & \multirow[b]{2}{*}{0.360} & 1090 & 3.062 & 67 & طلاب & \multirow{2}{*}{ ه- ضمان جودة البرنامج } \\
\hline & & 0.944 & 2994 & 31 & طالبات & \\
\hline \multirow[b]{2}{*}{0.325} & \multirow[b]{2}{*}{1.269} & 0.977 & 3.478 & 67 & طلاب & \multirow[t]{2}{*}{ المحاور مجتمعت } \\
\hline & & 0.964 & 3.237 & 31 & طالبات & \\
\hline
\end{tabular}

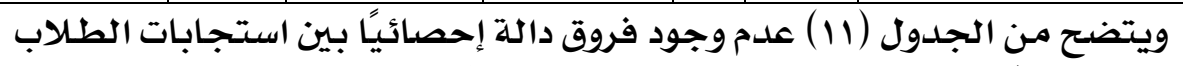

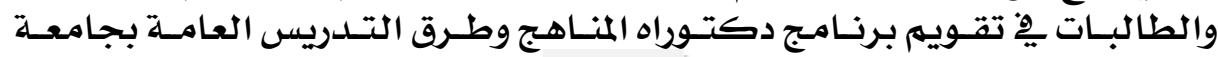




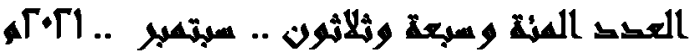

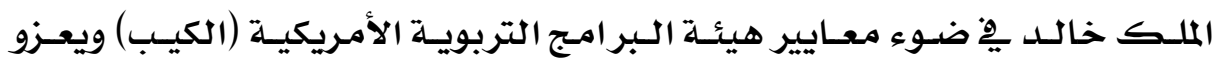

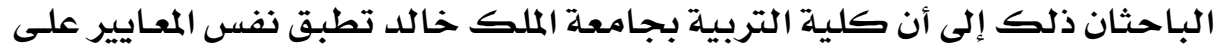

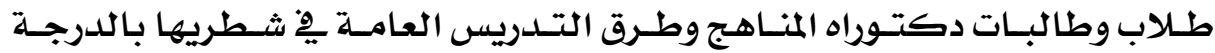

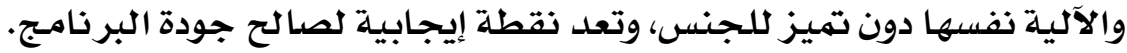

\section{• الإجابة عن السؤال الرئيس}

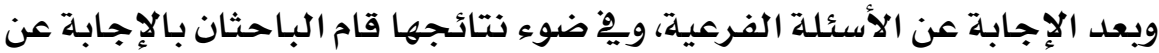

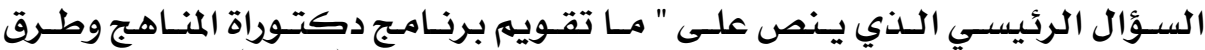

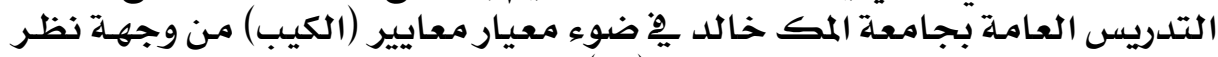

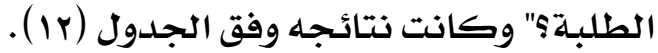

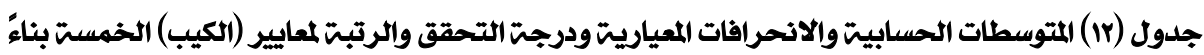
على تقويم أفراد العينت

\begin{tabular}{|c|c|c|c|c|}
\hline الترتيب & درجت التحقق & الانحراف المعياري & المتوسط الحسابي & 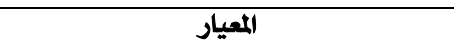 \\
\hline الثاني & كبيرة & .99 & r.o & ا - المحتوى والمعرفت التربويت \\
\hline الرابع & متوسط & .90 & r.Y & r- الشراكت المهنيت والتدريب الميداني \\
\hline الأول & كبيرة & 1.4 & r.A & r- جودة الطالب والانتقائيت \\
\hline الثالث & كبيرة & 1.17 & $r . \varepsilon$ & ع- أثر البرنامج \\
\hline 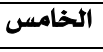 & متوسط & 1.12 & r.* & ه- ضمان جودة البرنامج والتحسين المستمر \\
\hline & كبيرة & 1.0 & r.\& & المتوسط العام \\
\hline
\end{tabular}

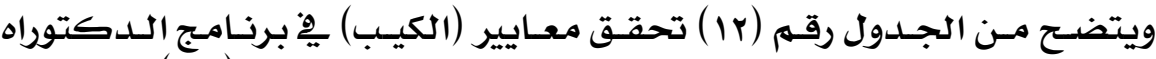

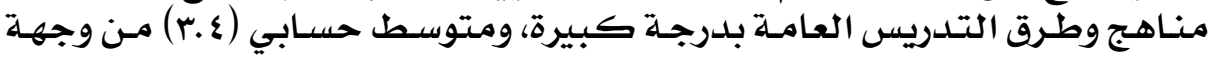

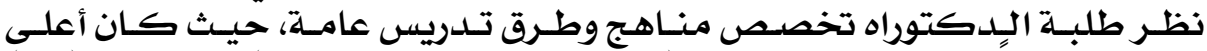

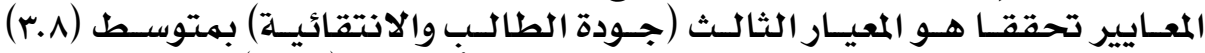

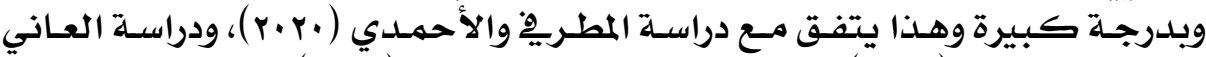

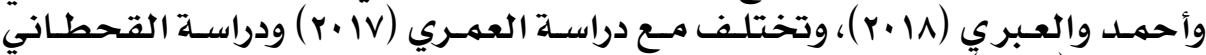

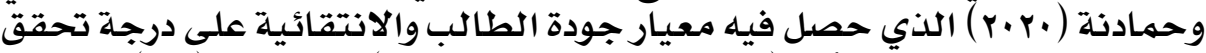

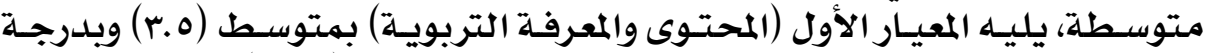

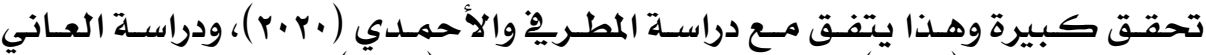

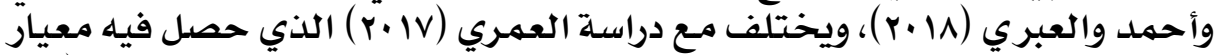

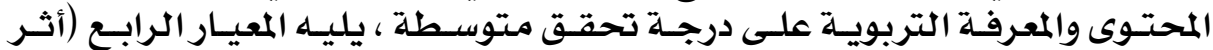

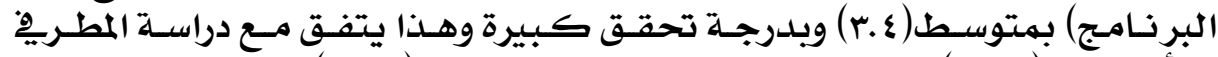

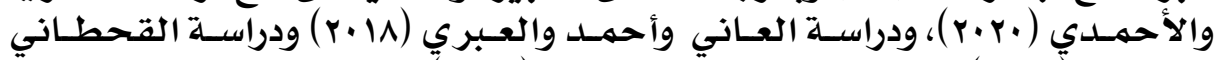

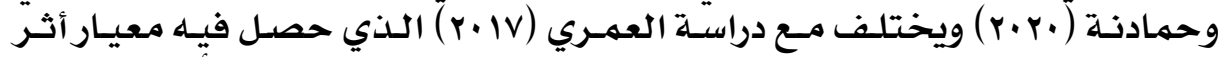

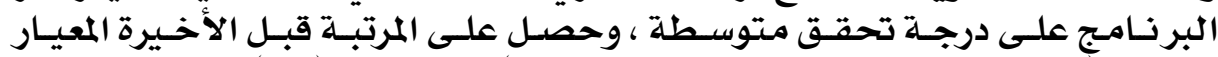

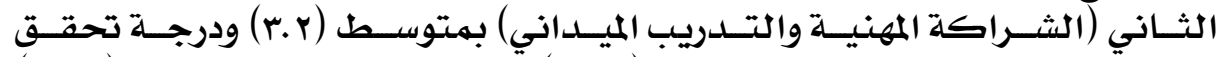

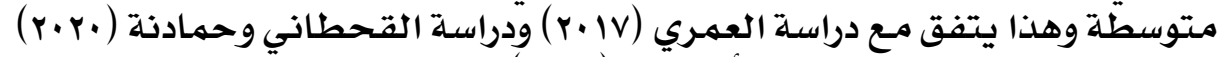

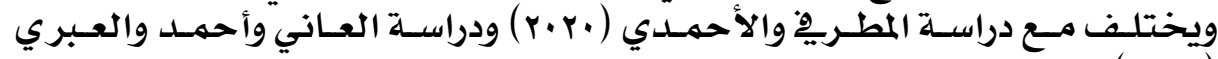

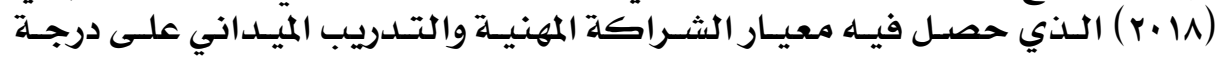




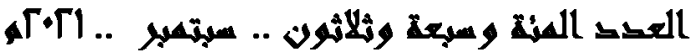

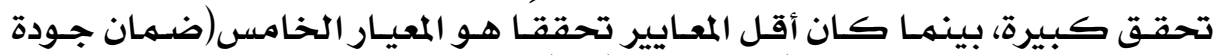

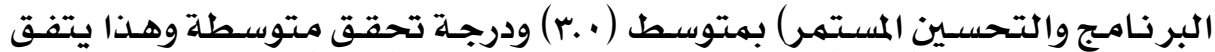

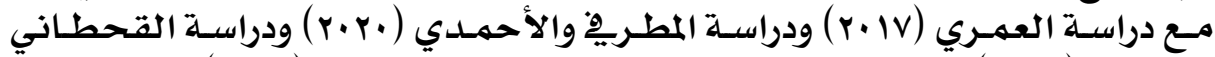

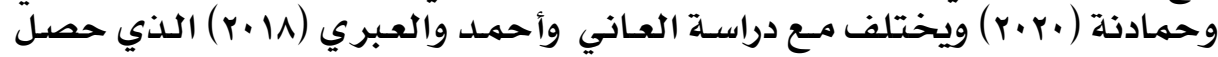

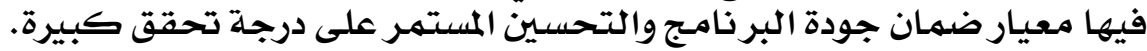

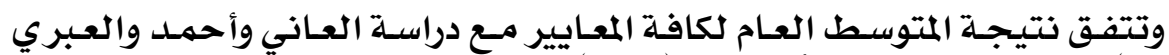

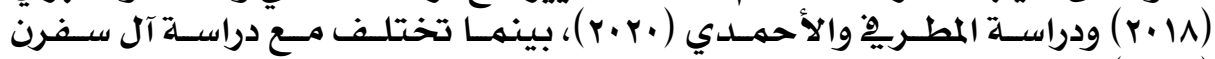

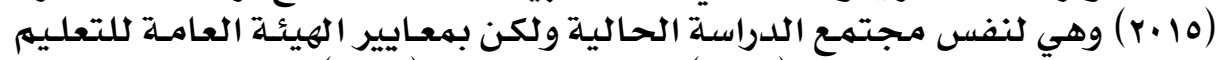

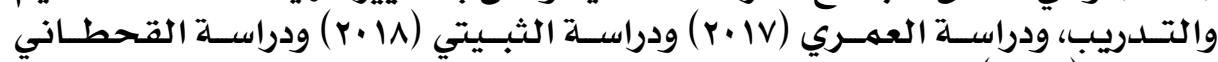

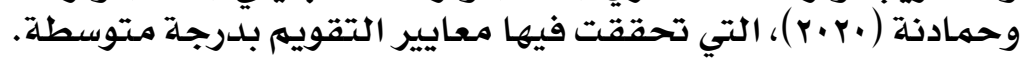

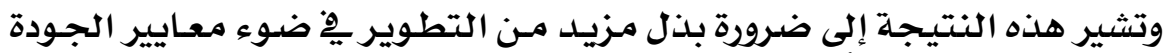

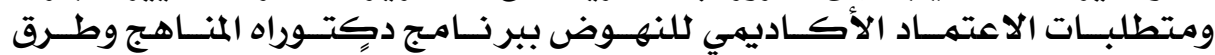

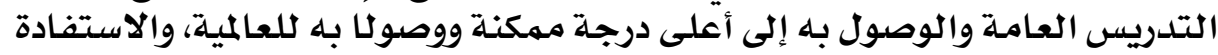

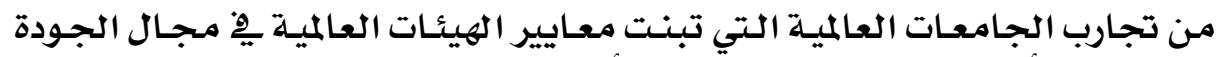

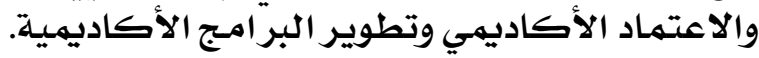

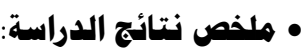

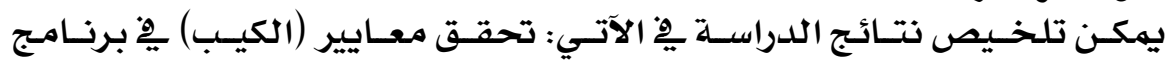

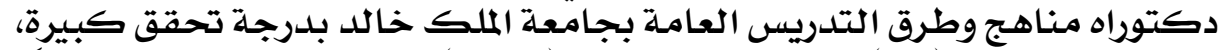

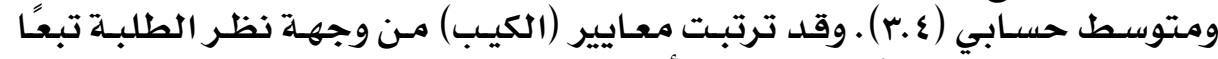

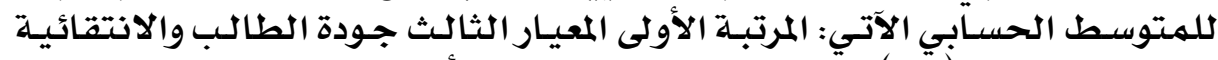

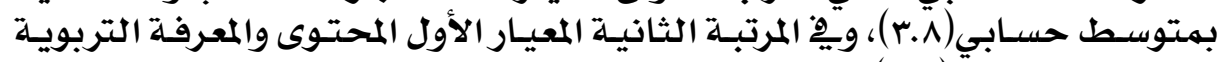

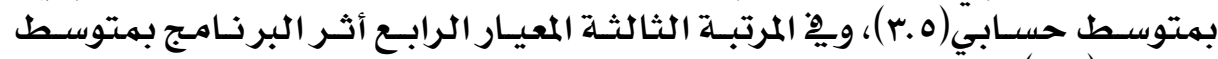

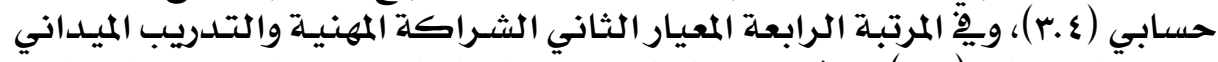

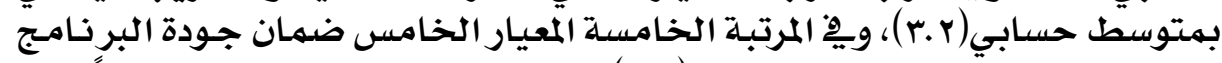

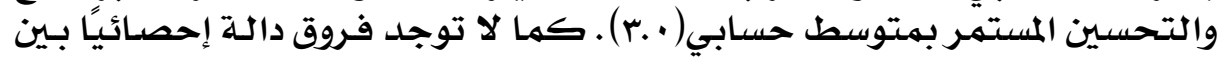

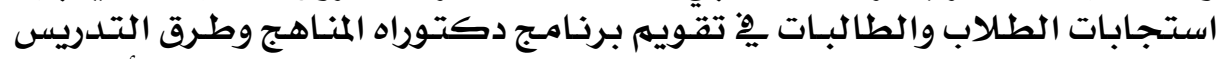

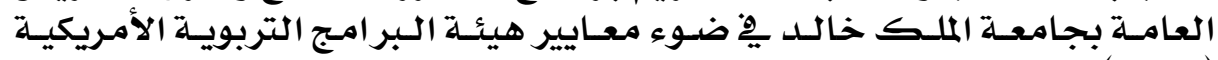
(الكيب) بعامبان.

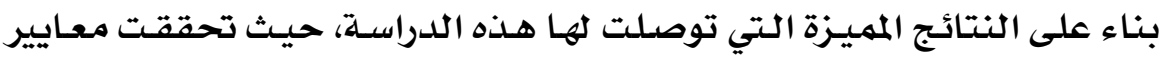

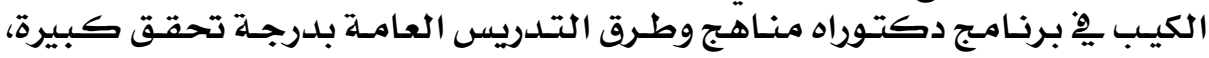

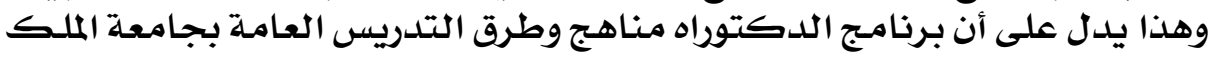

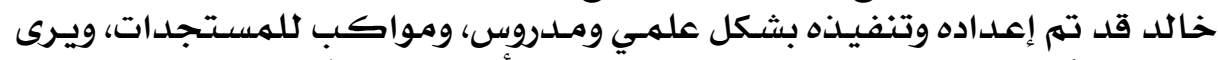

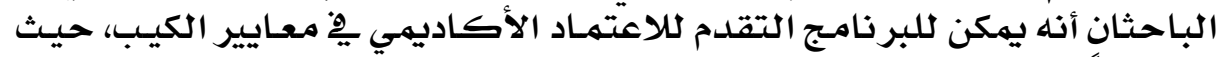

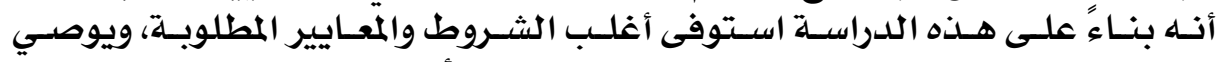

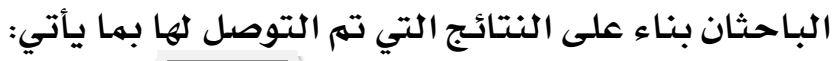




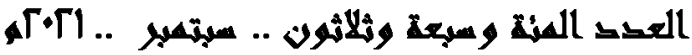

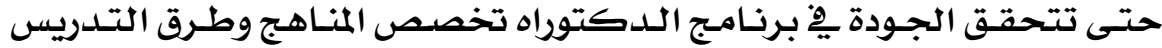

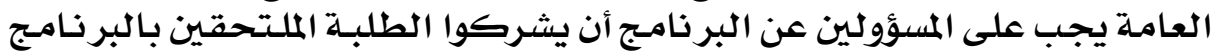

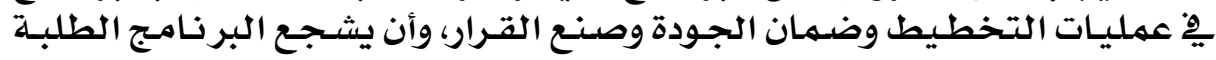

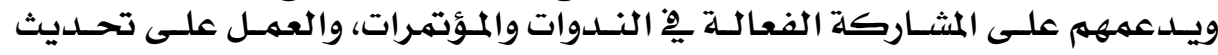

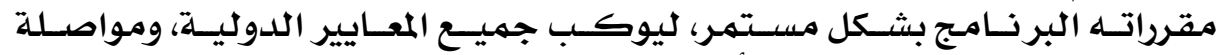

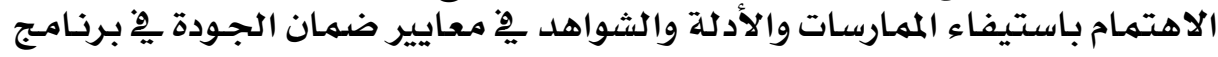

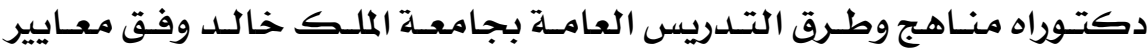

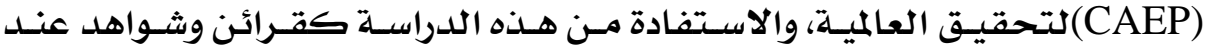

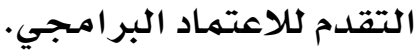

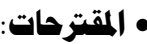

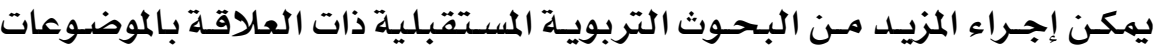

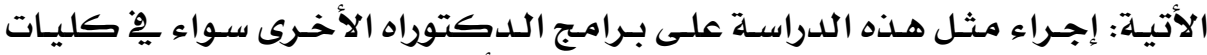

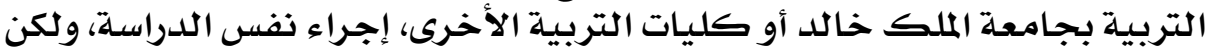

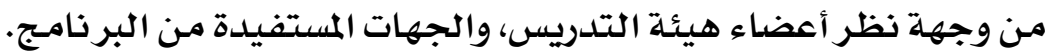

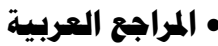

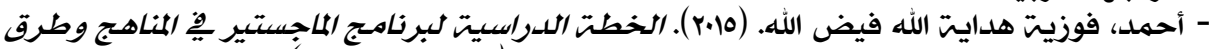

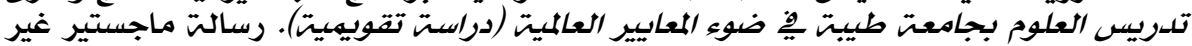

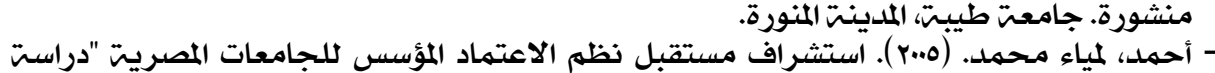

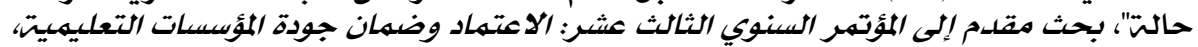

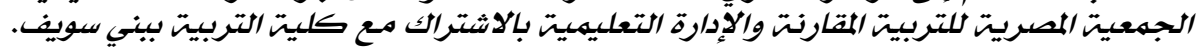

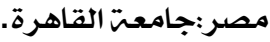

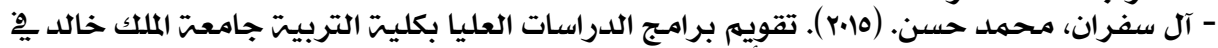

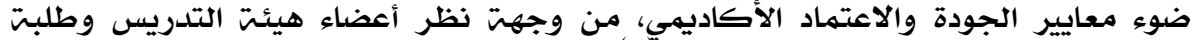

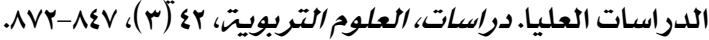

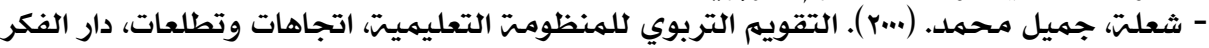

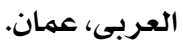

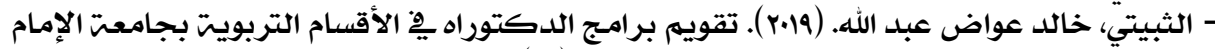

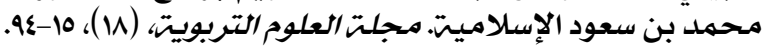

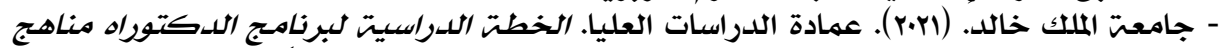

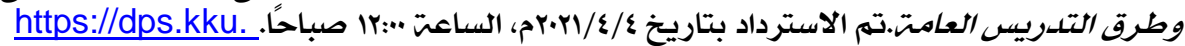
edu.sa/ar/content/365

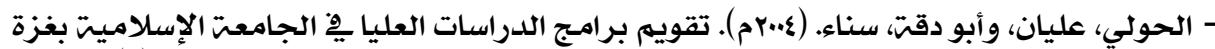

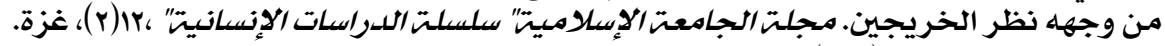

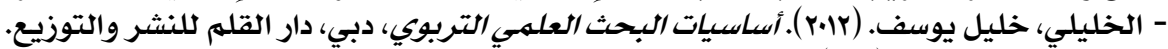

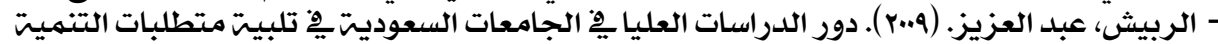

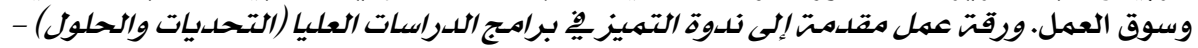

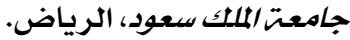

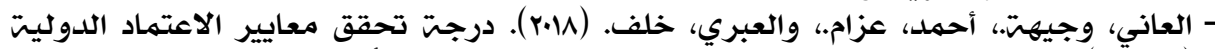

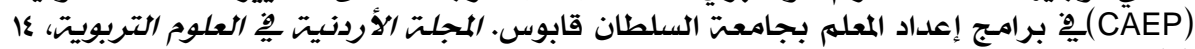
ب.r-rAr، (r) 


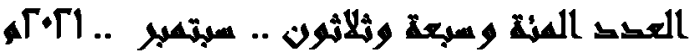

- العتيبي، خالد بن عبد الله. (...rم). تقوبيه برامج الدراسات العليا يِّ الجامعات السعوديت، مطابع جامعت الملكك سعود، الرياضئ

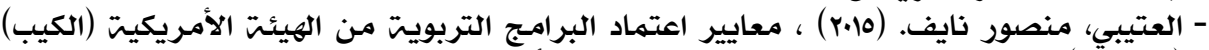

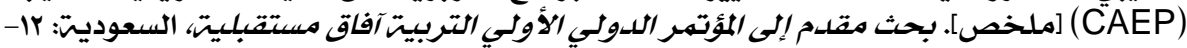
أبريل. جامعت الباحتة.

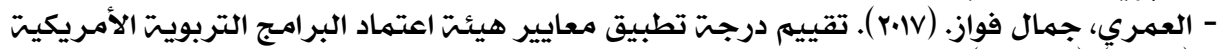
(الكيب) (CAEP)

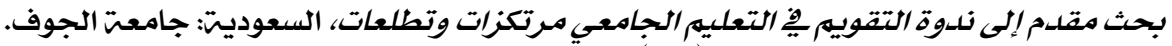

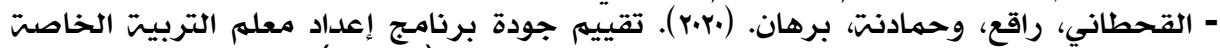

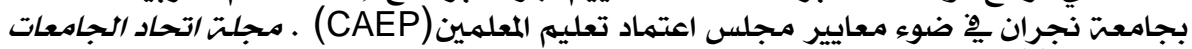

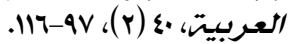

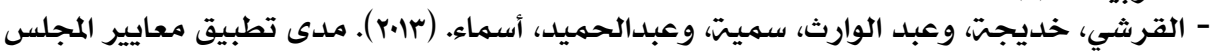

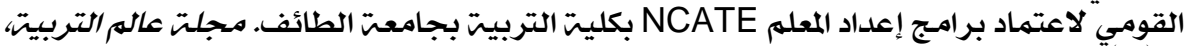

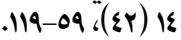

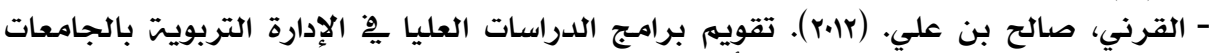

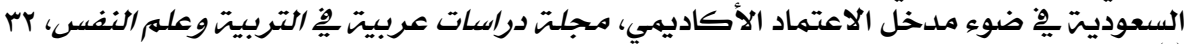
(1)، السعوديت. (1) السوديت.

- كليت التربيت (د.ت). خطتة برنامـج دكتوراه مناهـج وطرق التدريس العامت. بحث غير منشور. جامعت المللك خالد.

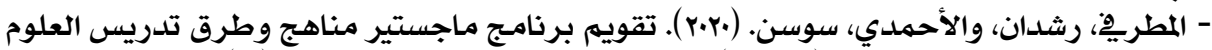

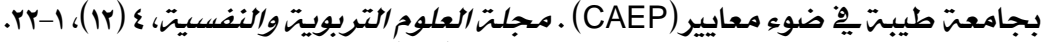

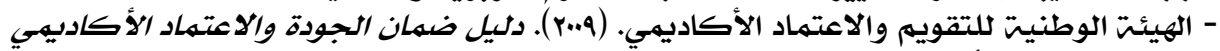

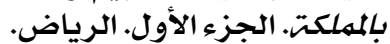

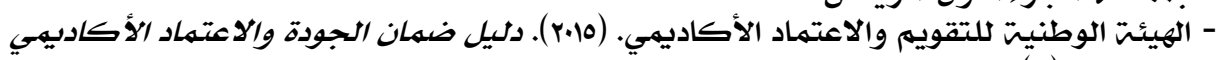

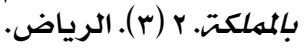

• مالمراجع الأجنبية:

- Almatrafi, R. T. (2015). Saudi faculty members' perceptions of CAEP standards (Order No. 3733175) Available from ProQuest Central. (1736047951). Retrieved from

- https://search.proquest.com/docview/1736047951?accountid=34864

- Council for the accreditation of educator preparation (CAEP). the cape standards. Retrieved from (4/4/2021) CAEP Standards for Accreditation at the Advanced-Level - Council for the Accreditation of Educator Preparation (caepnet.org)

\section{米米米米米米}

